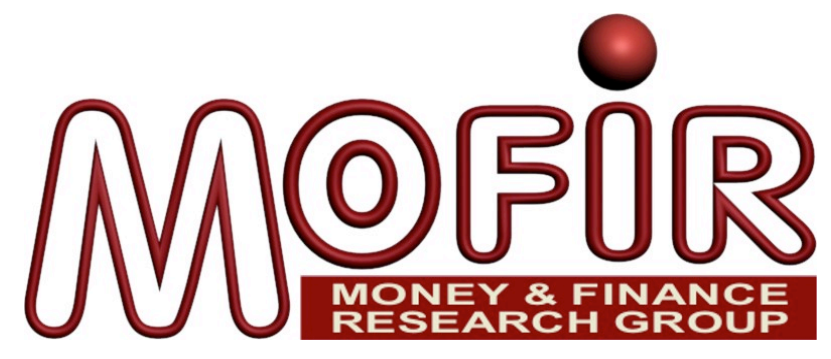

\title{
Public DEBT AND ECONOMIC GROWTH: IS THERE A CAUSAL EFFECT?
}

\author{
UGO PANIZZA \\ UNCTAD \\ ANDREA F. PRESBITERo \\ Università Politecnica delle Marche \\ MoFiR \\ CeMaFiR
}

MoFiR working paper $n^{\circ} 65$

April 2012 


\title{
Public Debt and ECONomic Growth: Is There a CAusal EFFECT?
}

\author{
Ugo Panizza Andrea F. Presbitero*
}

April 2, 2012

\begin{abstract}
This paper uses an instrumental variable approach to study whether public debt has a causal effect on economic growth in a sample of OECD countries. The results are consistent with the existing literature that has found a negative correlation between debt and growth. However, the link between debt and growth disappears once we instrument debt with a variable that captures valuation effects brought about by the interaction between foreign currency debt and exchange rate volatility. We conduct a battery of robustness tests and show that our results are not affected by weak instrument problems and are robust to relaxing our exclusion restriction.
\end{abstract}

JEL Codes: F33, F34, F35, O11

Keywords: Government Debt, Growth, OECD countries.

\footnotetext{
*Ugo Panizza, UNCTAD and The Graduate Institute, Geneva. E-mail: ugo.panizza@unctad.org. Andrea F. Presbitero, Department of Economics and Social Sciences - Università Politecnica delle Marche (Italy), Money and Finance Research group (MoFiR) and Centre for Macroeconomic and Finance Research (CeMaFiR). E-mail: a.presbitero@univpm.it; personal webpage: https://sites.google.com/site/presbitero/. We would like to thank, without implications, Alessandro Missale for sharing his data on the composition of government debt, Madhu Mohanty for providing us with details on the estimation procedures in his joint paper with Stephen Cecchetti and Fabrizio Zampolli, Aart Kraay for sharing his code for the calculations of Bayesian bounds in IV estimates and Jack Lucchetti for translating that code in GRETL. We would also like to thank Mr. Denis Pètre of BIS and the staff of the debt management offices of several OECD countries for helping us collecting data on debt composition. Finally, we would like to thank Mackie Bahrami, Carlo Cottarelli, Alessandro Missale, Andy Powell and Jaejoon Woo for comments on an earlier draft of the paper. The views expressed in this paper are the authors' only and need not reflect, and should not be represented as, the views of the United Nations.
} 


\section{Introduction}

Do high levels of public debt reduce economic growth? This is an important policy question. A positive answer would imply that, even if effective in the short-run, expansionary fiscal policies that increase the level of debt may reduce long-run growth, and thus partly (or fully) negate the positive effects of the fiscal stimulus.

Most policymakers do seem to think that debt reduces long-run economic growth. ${ }^{1}$ This view is in line with the results of a growing empirical literature which shows that there is a negative correlation between public debt and economic growth in advanced and emerging economies, and finds that this correlation becomes particularly strong when public debt approaches 100 percent of GDP (Reinhart and Rogoff, 2010a,b; Kumar and Woo, 2010; Checherita and Rother, 2010; Cecchetti, Mohanty and Zampolli, 2011). ${ }^{2}$

Correlation, however, does not imply causation. The link between public debt and economic growth could be driven by the fact that it is low economic growth that leads to high levels of debt. Alternatively, the observed correlation between debt and growth could be due to a third factor that has a joint effect on these two variables. Establishing the presence of a causal link going from debt to growth requires finding an instrumental variable that has a direct effect on debt but no direct (or indirect, except for the one going through debt) effect on economic growth.

In this paper, we propose a new instrument for public debt and show that instrumental variable regressions do not provide evidence that public debt causes growth in a sample of OECD countries. Our instrumental variables strategy relies on the fact that, in the presence of foreign currency debt, changes in a country's exchange rate have a direct and mechanical effect on the debt-to-GDP ratio. We thus collect detailed data on the currency composition of public debt and match them with data on bilateral exchange rates to build a variable that captures valuation effects brought about by exchange rate movements.

The first requisite for a good instrument is relevance: the instrument needs to be correlated with the endogenous variable. A battery of weak instrument tests confirm that our instrument is relevant. Nevertheless, we are aware that, by itself, our valuation effect variable does not satisfy the second requirement for a good instrument (instrument exogeneity). Valuation effects are mechanically correlated with the exchange rate which, in turn, may affect economic growth (Rodrik, 2008). Our instrument is also correlated with the share of foreign currency debt, and the latter may have an effect on economic growth, perhaps through increased volatility (Eichengreen, Hausmann and Panizza, 2005).

However, we see no reason why our valuation effect variable, built using bilateral data, should have a direct effect on economic growth once we control for debt composition and the behavior of the effective exchange rate.

While we are convinced of the soundness of our exclusion restriction, we cannot provide a formal test of its validity because our model is exactly identified, and exclusion restrictions can only be tested in overidentified models. We will thus use a Bayesian approach developed by Kraay (2012) to show that small violations of our exclusion restriction do not affect our results.

\footnotetext{
${ }^{1}$ For instance, the Director of the IMF Fiscal Affairs Department argued that: "in addition to problems for growth arising from a debt crisis, one should also be worried about problems for growth arising from high, even if stable debt." (Cottarelli, 2011). A related question that we do not address in this paper is whether fiscal expansions always lead to an increase in debt. For a discussion covering different points of view see: Cafiso and Cellini (2012), DeLong and Summers (2012), Gros (2011), Krugman (2011), Sutherland, Hoeller and Merola (2012), and UNCTAD (2011)

${ }^{2}$ There is also an older literature which focuses on developing countries and looks at the relationship between external debt and economic growth. This literature also finds that the debt is negatively correlated with economic growth and that this correlation becomes particularly strong when debt reaches a certain threshold (Pattillo, Poirson and Ricci, 2011; Cordella, Ricci and Ruiz-Arranz, 2010).
} 
The existing literature found that the negative correlation between debt and growth becomes particularly strong when debt approaches 100 percent of GDP (Reinhart and Rogoff, 2010a,b; Cecchetti, Mohanty and Zampolli, 2011; Checherita and Rother, 2010). We search for such a threshold in our data, but do not find strong evidence of a structural break. Since our findings do not rule out the presence of a threshold in the longer and larger datasets studied by other authors, we also experiment with instrumental variable regressions in high and lowdebt subsamples. In low-debt countries, we still find that the negative correlation between debt and growth disappears once we instrument debt with our valuation effect variable. However, our instrument does not perform well in the high-debt subsample. We thus use an alternative identification strategy based on Fisher's (1966) covariance restrictions, and find no evidence of a negative correlation between debt and growth in high-debt countries.

In order to compare our results with those of the existing literature, we build on the influential paper by Cecchetti et al. (2011). Our work is also closely related to the historical work of Reinhart and Rogoff $(2009,2010 a, b)$. Our scope, however, is much narrower than that of these papers. In particular, we concentrate on government debt and, unlike Cecchetti et al. and Reinhart and Rogoff, we do not explore the complex interactions between private and public debt.

\section{Addressing Endogeneity}

In this section we discuss the endogeneity problem that affects the literature on debt and growth, assess the likely direction of the bias, describe how the existing literature dealt with endogeneity, and then illustrate our instrument.

The easiest way to describe the endogeneity problem and assess the likely direction of the bias is to use a simple bivariate model in which growth $(G)$ is a function of debt $(D)$ :

$$
G=a+b D+u
$$

and debt is a function of growth:

$$
D=m+k G+v .
$$

The OLS estimator of $b$ is then given by:

$$
\widehat{b}=\frac{b \sigma_{v}^{2}+k \sigma_{u}^{2}}{\sigma_{v}^{2}+k^{2} \sigma_{u}^{2}}
$$

and the bias of the OLS estimates is:

$$
E(\widehat{b})-b=\frac{k(1-b k)}{\sigma_{v}^{2} / \sigma_{u}^{2}+k^{2}} .
$$

Equation (3) shows that OLS estimations are unbiased if $k=0$ (i.e., if debt is not endogenous) or if, for some coincidence, $b k=1$. If $k$ is negative (as it is likely to be) and $b k<1$ (this is always the case if $b$ is non-negative), OLS estimates are negatively biased.

Of course, we are not the first to recognize that debt is likely to be endogenous. The existing literature tries to address endogeneity by using lagged values of the debt-to-GDP ratio (Cecchetti, Mohanty and Zampolli, 2011), GMM estimations with internal instruments (Kumar and Woo, 2010; Presbitero, 2012), and by instrumenting the debt-to-GDP ratio with the average debt of partner countries (Checherita and Rother, 2010).

While these are useful first steps, we think that they are inadequate to fully address endogeneity. The use of lagged variables is problematic because debt and growth tend to be 
persistent. ${ }^{3}$ The high persistence of debt ratios also limits their validity as internal instruments in the standard GMM estimators developed by Arellano and Bond (1991), Arellano and Bover (1995), and Blundell and Bond (1998). Moreover, these difference and system GMM estimators are poorly suited for macroeconomic datasets with a relatively small number of cross-sectional units (Bond, 2002). Instrumenting public debt with that of neighboring countries is problematic in the presence of global shocks and financial and real spillovers. If a shock to country $i$ 's GDP growth has an effect on country $j$ 's GDP growth, the evolution of public debt in country $i$ cannot be used as an instrument for public debt in country $j .{ }^{4}$

We propose to address the endogeneity issue by instrumenting the debt-to-GDP ratio with the valuation effect brought about by the interaction between foreign currency debt and movements in the exchange rate.

Formally, let us consider a country that has issued public debt denominated in $N$ currencies (this set of $N$ currencies may include the domestic currency). Let us further define $D_{i j}$ as the stock of debt issued by country $i$ and denominated in currency $j$, and $e_{i j}$ as the $\log$ of the exchange rate between currency $i$ and currency $j$. We then propose to instrument the stock of public debt of country $i$ in period $t+1$ with the following variable:

$$
V E_{i, t}=\frac{\sum_{j=1}^{j=N} D_{i j, t}\left(e_{i j, t+1}-e_{i j, t}\right)}{\sum_{j=1}^{j=N} D_{i j, t}} .
$$

To be a good instrument, $V E$ needs to be relevant (i.e., it needs to be correlated with public debt) and exogenous (i.e., it should not belong in the growth regression). We will start by discussing relevance and then move to exogeneity.

Relevance may appear to be guaranteed by the fact that there is a mechanical relationship between $V E$ and the debt-to-GDP ratio. However, things are complicated by the fact that $V E$ is always equal to zero (and therefore useless as instrument) for countries that do not have foreign currency debt (because, by definition, $e_{i j, t+1}-e_{i j, t}=0$ ) or have very stable exchange rates. ${ }^{5}$ This would not be a concern if we were to focus on emerging market countries which tend to have large foreign currency debt and high exchange rate volatility (Hausmann, Panizza and Rigobon, 2006). Relevance may instead be a problem in our sample of OECD countries.

Table 1 reports country-by-country summary statistics of $V E$. It shows that the variance of $V E$ is close to zero in France, Germany, Japan, the Netherlands, and the United States. This is not surprising as these five countries do not have public debt denominated in foreign currency. In the remaining 12 countries, the variance of $V E$ ranges between 0.15 percent and 1.89 per cent. The overall variance of $V E$ is approximately 1 percent. The cross-country variance is 0.26 percent and the within-country variance is 0.94 percent.

Whether this variance is sufficient to make of $V E$ a relevant instrument for public debt is an empirical question that can be assessed using appropriate statistical tests. While we postpone the discussion of these tests to the next section, we now show that there is a positive and

\footnotetext{
${ }^{3}$ Moreover, policymakers who anticipate a growth slowdown may put in place expansionary fiscal policies aimed at attenuating the slowdown. The increase in debt would thus precede the slowdown but still be caused by the recession.

${ }^{4}$ Panizza and Jaimovich (2007) show that trading partners' output growth is a good instrument for GDP growth. As a consequence, trading partners' debt is unlikely to be a good instrument for public debt.

${ }^{5} V E$ is not necessarily equal to zero for countries that have a fixed exchange rate. This would only be the case if all the foreign currency debt is denominated in the currency to which these countries fix their exchange rate.
} 
statistically significant partial correlation between the lagged value of $V E$ and the stock of public debt.

Our point estimates suggest that a one percentage point increase in lagged $V E$ is associated with a 1.5 percentage points increase in the debt-to-GDP ratio (Figure 1). The results are almost identical if we estimate the model without Japan (Figure 2) and become somewhat stronger if we estimate the model by dropping the five countries with the smallest shares of foreign currency debt (Figure 3). In all cases, the coefficient is positive and statistically significant at the one percent confidence level.

We now turn to exogeneity. Since our model is exactly identified we cannot test the validity of our exclusion restriction. Therefore, we need to defend our identification strategy on theoretical grounds. We believe that there are two possible reasons why $V E$ may have an effect on economic growth. The first has to do with the fact that $V E$ is likely to be correlated with the presence of foreign currency debt. ${ }^{6}$ Foreign currency debt, in turn, may reduce a country's ability to implement countercyclical macroeconomic policies and thus increase volatility and reduce growth (Eichengreen, Hausmann and Panizza, 2005; Hausmann and Panizza, 2011).

The second reason relates to the fact that $V E$ is a debt-weighted (instead of trade-weighted) effective exchange rate. ${ }^{7}$ Even though the weights are different, $V E$ could thus be correlated with the trade-weighted real effective exchange rate which, in turn, has been shown to have an effect on economic growth. In particular, Rodrik (2008) shows that the real exchange rate is an important driver of economic growth and that undervalued exchange rates are associated with higher economic growth. ${ }^{8}$

If these are the only two channels through which $V E$ may affect growth, controlling for the share of foreign currency debt and the level of the real exchange rate will eliminate any direct or indirect (except for the one that goes through public debt) correlation between $V E$ and economic growth. In other words, our exclusion restriction is valid as long as we control for debt composition and the level of the real exchange rate.

While we cannot think of any other channel through which $V E$ can affect economic growth, we are sure that creative skeptical readers will find ways to challenge our exclusion restriction. Therefore, we use Kraay's (2012) Bayesian approach to build confidence intervals for instrumental variable regressions with weak exclusion restrictions.

Our objective is to follow as closely as possible Cecchetti et al. (2011) who study a sample of 18 OECD countries for the period 1980-2005. However, the construction of $V E$ requires detailed information on the currency composition of public debt and these data are not generally publicly available. In order to build our instrument, we searched old statistical bulletins, and contacted the central banks and debt management offices of the OECD countries covered in the sample of Cecchetti et al. (2011). After months of detective work, we were able to obtain data for 17 of these 18 countries (the missing country is Greece). ${ }^{9}$ In the case of Portugal, our sample starts

\footnotetext{
${ }^{6}$ However, the direction of the correlation is not clear. In our data, the correlation between these two variables is positive $(0.22)$ and statistically significant at the 1 percent confidence level.

${ }^{7}$ Since $V E$ includes domestic debt, it is conceptually similar to a trade-weighted exchange rate multiplied by the degree of trade openness. In fact, Equation (4) can be rewritten as: $V E_{i, t}=\frac{\sum_{j \neq i}^{N-1} D_{i j, t}}{\sum_{j=1}^{N} D_{i j, t}} \frac{\sum_{j \neq i}^{N-1} D_{i j, t}\left(e_{i j, t+1}-e_{i j, t}\right)}{\sum_{j \neq i}^{N-1} D_{i j, t}}$. Where $\sum_{j \neq i}^{N-1} D_{i j, t}$ is total foreign currency debt, and $\frac{\sum_{j \neq i}^{N-1} D_{i j, t}}{\sum_{j=1}^{N} D_{i j, t}}$ is the share of foreign currency debt over total debt.

${ }^{8}$ Note that Rodrik works with the real exchange rate and $V E$ is a nominal (debt-weighted) effective exchange rate. However, most of the volatility of the real exchange rate is driven by the behavior of the nominal exchange rate (Mussa, 1986). Having said that, in our sample the correlation between $V E$ and the trade weighted effective exchange rate is positive but not even close to being statistically significant.

${ }^{9}$ Our main source of information is based on unpublished data that the Bank for International Settlements uses to build Table 13 B of its International Debt Securities Statistics. However, these data only go back to 1993.
} 
in 1993 because we were not able to find information on the currency composition of public debt in the 1980s and early 1990s. In the next section, we show that our slightly smaller sample can reproduce all the main results of the benchmark paper.

\section{Debt and Economic Growth: Causation versus Correlation}

To explore whether public debt has a causal effect on economic growth, we build on an influential paper of Cecchetti et al. (2011). We stay as close as possible to their work by using the same data, sample (with the exceptions mentioned in the previous section), and empirical approach. Formally, we use five-year overlapping growth spells to estimate the following regression:

$$
G R O W T H_{i, t+1, t+6}=\alpha y_{i, t}+\beta\left(\frac{D e b t}{G D P}\right)_{i, t}+\gamma^{\prime} X_{i, t}+\mu_{i}+\tau_{t}+\varepsilon_{i, t},
$$

where $y$ is the $\log$ of real GDP per capita, $\mu_{i}$ and $\tau_{t}$ are country and year fixed effects, $X_{i, t}$ is a matrix of control variables, and GROWTH is average growth of real GDP per capita in percentage terms (i.e., GROWT $\left.H_{i, t+1, t+6}=\left(y_{i, t+6}-y_{i, t+1}\right) * 100 / 5\right)$.

We are aware that using overlapping periods is not standard in the growth literature (notable exceptions include Bekaert, Harvey and Lundblad (2001, 2005)). However, in our small sample of 17 countries, using non-overlapping growth spells would have a large cost in terms of the efficiency of our estimations. Therefore, we use overlapping growth periods and do our best to correct for the fact that this choice imposes a moving average structure on the error term. We also experiment with non-overlapping growth spells and find results that are consistent (albeit much weaker) with those of our benchmark specification.

Even though our specification includes lagged GDP, we think that the commonly used difference and system GMM estimators are not well suited for a sample, like ours, with a relatively small number of cross-sectional units (Bond, 2002). In fact, we did experiment with difference and system GMM estimators and found that the specification tests always reject the validity of our model. ${ }^{10}$

\subsection{Baseline estimations}

We start with a baseline model in which GDP growth is regressed on lagged values of the public debt-to-GDP ratio, the log of initial GDP per capita, national gross savings (as a share of GDP), population growth, average number of years of secondary education, trade openness, inflation, age dependency ratio (the ratio between people younger than 15 or older than 64 and people in the 15-64 age range), a banking crisis dummy, and the ratio of liquid liabilities to GDP. ${ }^{11}$

For previous periods, we consulted national statistical sources (we used the same sources listed in the Appendix of Missale (1999)) and, in some cases, obtained confidential data from national debt agencies and central banks. We deal with missing data by interpolating individual currency shares and then using data from Missale (1999) to measure the overall foreign currency share. Post-1992 data are of of higher quality with respect to the pre-1993 data which are from heterogeneous sources and were sometimes interpolated. The fact that measurement error is larger in the pre-1993 data weakens our instrument but should not lead to any obvious bias. As expected, the within-country correlation between our instrument and debt is stronger in the after 1993 sample than in the whole sample.

${ }^{10}$ In particular, we estimated Equation (5) with the difference and system GMM estimators and experimented with different sets of instruments and allowed for different lag structures in the instruments. We found that public debt had a negative coefficient (often statistically insignificant, but sometimes significant) and that using $V E$ as an external instrument had no effect on the magnitude and significance level of the public debt coefficient. However, our models were always rejected by the standard specification tests. In particular, AR2 was always statistically significant and, in many cases, the Sargan test rejected the validity of the exclusion restrictions.

${ }^{11}$ These are the same controls used in Column 2 of the top panel of Table 5 and in column 3 of Table A3.1 of Cecchetti et al. (2011). 
The point estimates of the OLS regression reported in column 1 of Table 2 suggest that a ten percentage point increase in the debt-to-GDP ratio is associated with an 18 basis point reduction of average growth. This is very close to the baseline estimate of Cecchetti et al. (2011) who find a 17 basis point effect. The coefficient of public debt appears to be precisely estimated and is statistically significant at the one percent confidence level. Therefore, even though we have a slightly different sample, our baseline results are almost identical to those of the benchmark paper.

When we instrument the debt-to-GDP ratio with L.VE, we find a strong positive first stage correlation between the instrument and public debt (column 2 of Table 2; this is the same partial correlation plotted in Figure 1). More interestingly, the second stage regression of column 3 shows that debt is no longer statistically significant, and that its coefficient goes from negative to positive.

While the lack of statistical significance could be due to the fact that the IV estimator is inefficient, the change in sign is prima facia evidence that the OLS estimates suffer from a large negative bias. This is exactly what we would expect if there were a negative causal effect going from growth to public debt ( $k<0$ in the discussion of the previous section).

The bottom panel of Table 2 reports a battery of underidentification and weak instrument tests. The Kleibergen-Paap LM and Wald statistics reject the null of underidentification. We are thus confident that our instrument satisfies the rank condition. The Kleibergen-Paap F test yields a value of 9.2. This is close to the Staiger and Stock (1997) rule of thumb value of 10, and it is in between the Stock and Yogo (2005) 5 percent critical values for 10 and 15 percent maximum bias (these critical values are 16.38 and 8.96, respectively). Therefore, the maximum bias associated with the possible presence of weak instruments can be larger than 10 percent but it is smaller than 15 percent. Angrist and Pischke (2009) argue that the weak instrument bias tends to be small in exactly identified models like ours and that the bias disappears when the correlation between the instrument and the endogenous variables is greater than 0.1 (the Staiger-Stock rule of thumb requires a correlation of at least 0.3 ).

Even though the tests reported in the bottom panel of Table 2 and the findings of Angrist and Pischke (2009) suggest that our estimations are unlikely to suffer from weak instruments bias, we can use Moreira's (2003) conditional likelihood ratio test (CLRT) to build confidence intervals that are valid in the presence of weak instruments. When we compare the IV confidence interval with the CLRT confidence interval, we find that the latter is wider (-5.31, 19.39 instead of $-6.8,7.4)$ but shifted to the right with respect to the IV confidence interval. This is not surprising because, if anything, the presence of weak instruments may bias the IV estimator towards the OLS estimator. This is another reason why we think that our estimations provide convincing evidence that there is no proof that debt has a causal effect on economic growth.

Until now we have not controlled for currency composition and the effective exchange rate. Therefore, the model of Table 2 is likely to be misspecified (see the discussion in Section 2). In Table 3, we augment the baseline specification with a variable that captures the share of foreign currency debt and the (trade-weighted) real effective exchange rate index (higher values of the index are associated with real appreciations). As we include these two variables to eliminate any possible channel through which L.VE may affect growth, we also lag currency composition and the real exchange rate index..$^{12}$

As before, OLS estimations find a negative and statistically significant correlation between debt and economic growth (Column 1 of Table 3). The point estimate implies that a 10 percentage point increase in the debt to GDP ratio is associated with a 15 basis point decrease in growth. Again, the coefficient is precisely estimated and is statistically significant at the

\footnotetext{
${ }^{12}$ Given that the control variables are lagged with respect to the beginning of the growth episode, $V E$, currency composition, and the real exchange rate index are actually lagged twice.
} 
one percent confidence level. As expected, we also find that foreign currency debt and real appreciations are negatively correlated with GDP growth.

The first stage regressions of column 2 shows a strong positive correlation between L.VE and the debt-to-GDP ratio. The Kleibergen-Paap LM and Wald statistics are now higher than in Table 2, and always reject the null of underidentification at the five percent confidence level. The Kleibergen-Paap first stage F test now takes a value of 16 . This is well above the Staiger and Stock (1997) rule of thumb value, and approximately equal to the Stock and Yogo (2005) threshold for a maximum 10 percent bias (the exact value of the threshold is 16.38). In the second stage of the IV regression, we find that the coefficient of public debt changes sign and becomes statistically insignificant (column 3 of Table 3). As before, we find that controlling for endogeneity eliminates the negative correlation between public debt and GDP growth. At 2.05, the point estimate looks implausibly large. However, the $t$ statistics is 0.5 and the coefficient is not even close to being statistically significant. Again, we find that the CLRT confidence interval is shifted to the right and wider than the IV confidence interval.

While fixed effects estimations allow controlling for unobserved time-invariant heterogeneity and attenuate potential omitted variable bias, they also reduce the signal to noise ratio (the signal is the deviation from the mean) and amplify the consequences of measurement error. Moreover, since fixed effects estimations concentrate on how within-country changes in debt affect withincountry changes in growth, they may not capture the possible costs of "structurally" high levels of debt. ${ }^{13}$ However, our results are not driven by the presence of fixed effects. To the contrary, in the non-instrumented regressions, the negative correlation between debt and growth is stronger (and more precisely estimated) when we include country and year fixed effects. Moreover, our sample does not include any country with "structurally" high levels of debt (for instance, at the beginning of our sample, Italy and Japan's debts were below 70 percent of their respective GDP). As a consequence, the within-country variance of the debt-to-GDP ratio is similar to its between-country variance.

We think that our baseline estimations of Tables 2 and 3 provide convincing evidence that in OECD countries there is no causal link going from public debt to economic growth. We already showed that the lack of a statistically significant effect of debt in the IV regressions is unlikely to be caused by the presence of weak instruments. We now conduct an extensive battery of robustness checks aimed at uncovering possible problems with our estimation strategy.

\subsection{Weak Exclusion Restrictions}

The key assumption in our estimation strategy is that L.VE does not belong in the growth equation. Since our model is exactly identified, we cannot provide a statistical test of the validity of this restriction. We can, however, use Kraay's (2012) Bayesian approach to check what happens if we relax our exclusion restriction.

To illustrate Kraay's approach, let us go back to Equation (1) in which growth $(G)$ is a function of debt $(D)$. Since debt is endogenous, $E(D, u) \neq 0$ and the OLS estimator is biased. If we can find a variable $Z$ correlated with $D$ but uncorrelated with $u$, we can recover the structural parameter of interest. However, the assumption that $E(Z, u)=0$ "is likely to be a poor approximation to the actual prior belief of empirical researchers." (Kraay, 2012, p. 112).

Relaxing the assumption that the distribution of $E(Z, u)$ collapses at zero does not prevent us from identifying the structural parameters of interest, but it does reduce the precision of the structural estimates (Kraay, 2012). Kraay's Bayesian approach quantifies the consequence of

\footnotetext{
${ }^{13}$ Our definition of "structurally high" debt is different from that of "structural" debt in Powell (2012). The former refers to debt levels that remain persistently high and therefore do not change much over time. The latter refers to the level of debt net of valuation effects.
} 
prior uncertainty on the validity of the exclusion restriction and maps the degree of uncertainty on the precision of the estimate of the structural parameter.

Specifically, Kraay uses a prior distribution for the correlation between the reduced form error and the instrument to approximate prior uncertainty about the validity of the exclusion restriction. In particular, let $\phi$ be a uniformly distributed random variable over the support $(-1,1)$ and $1 / \eta$ the degree of prior uncertainty about the validity of the exclusion restriction. Kraay's prior distribution $g(\phi)$ is then given by:

$$
g(\phi)=\left(1-\phi^{2}\right)^{\eta}
$$

Prior uncertainty reaches its maximum level $(g(\phi)$ is uniformly distributed over $-1,1)$ when $\eta=0$. The higher the value of $\eta$, the lower the uncertainty. Setting $\eta=5$ is equivalent to assuming a 90 percent prior probability that $g(\phi) \in(-0.46,0.46)$. With $\eta=100$, the 90 percent confidence interval for $g(\phi)$ is $(-0.12,0.12)$, and with $\eta=500$ there is a 90 percent probability that $g(\phi) \in(-0.05,0.05)$ (the 90 percent confidence interval drops to -0.04 and 0.04 for $\eta=1000$; see Table 1 in Kraay (2012)).

Having found a method to characterize prior uncertainty, Kraay shows that it is possible to use numerical sampling to map this prior uncertainty on the posterior marginal distribution of the structural parameters. ${ }^{14}$ His simulations show that even moderate prior uncertainty can have a large effect on the precision of the estimated parameters. Perhaps surprisingly, he shows that the loss of precision linked to prior uncertainty is higher in the presence of strong instruments and large samples. In other words, the stronger the instrument, the more serious the consequence of a misspecified model.

When we use Kraay's approach to examine the consequence of weakening our priors about the validity of our exclusion restriction, we find that a strong violation of our exclusion restriction yields very large confidence interval (Table 4). In particular, when $\eta \leq 10$ (implying that there is a 90 percent probability that $g(\phi) \in(-0.34,0.34))$, the confidence intervals are five times larger than those of the IV regressions in which we assume that $g(\phi)=0$. When we set $\eta=100$ and thus limit the $90 \%$ confidence interval of $g(\phi)$ to $(-0.12,0.12)$, the confidence interval of the structural estimate becomes only slightly larger than that of the IV estimates (which assume $E(Z, u)=0)$.

We also find that relaxing our priors on the exclusion restriction has more serious consequences for the model in which we control for foreign currency share and debt composition (the last three columns of Table 4). This is not surprising. Our instrument is much stronger in the regressions in which we control for foreign currency share and debt composition, and Kraay shows that potential violations of the exclusion restriction are more problematic for models with stronger instruments.

\subsection{Other Robustness Checks}

\section{Placebo regressions}

An alternative way to check whether our results are driven by the presence of a weak instrument is to substitute our instrument with a randomly generated variable that matches the moments of L.VE. If this placebo IV regression were to give results similar to those of our IV regressions, we would know for sure that there is a problem with our instrument (Bound, Jaeger and Baker, 1995). Figure 4 plots the results of 1,000 replications of placebo IV regressions and Table 5 reports the summary statistics for the model that does not control for foreign currency share

\footnotetext{
${ }^{14}$ Since the moments of the posterior distribution of the structural parameters are not defined, Kraay (2012) summarizes his results with the median, $2.5^{t h}$ and $97.5^{t h}$ percentiles of the posterior distribution.
} 
and exchange rate (column 1) and for the full model (column 2). We find that the mean and median values of the placebo regression are similar to those of the OLS estimates but that they are imprecisely estimate. This is exactly what one would expect with a placebo instrument. More important, for our purpose, the results of the placebo regression are different from those of the IV regressions of Tables 2 and 3. While the results of Table 5 do not prove that our instrument is valid, they show that the instrument passes the non-robustness test proposed by Bound, Jaeger and Baker (1995).

\section{Dealing with autocorrelation}

As we use overlapping growth periods, the errors of our model have a moving average structure. So far, we dealt with serially correlated residuals by using the Huber-White sandwich correction. This estimation strategy is appropriate in the presence of within-country time dependence and heteroscedacity of unknown form. An alternative approach consists of using the Newey and West (1987) estimator which allows modeling the autocorrelation process in the error term. This is what we do in Table 6. In particular, we experiment with $\operatorname{AR}(1), \operatorname{AR}(5)$, and $\operatorname{AR}(10)$ error structures and find results which are basically identical to those of Table $3 .^{15}$

\section{An alternative measure of debt}

We also experiment with an alternative data source for our indebtedness variable. In particular, Table 9 replaces the debt-to-GDP ratio based on flow of funds national balance sheet statistics, with the debt-to-GDP ratio data described in Panizza (2008). ${ }^{16}$ While the regressions yield estimates similar to our baseline of Table 3, we now find that the instrument is much weaker. In particular, the first stage Kleibergen-Paap F test takes a value of 4.58. This is much lower than the Staiger and Stock (1997) rule of thumb and lower than the Stock and Yogo (2005) threshold for a 25 percent maximum bias.

\section{Different samples and outliers}

While the last growth spell considered by Cecchetti et al. (2011) is 2001-2006, we have more recent data and estimate regressions that include GDP growth over the 2002-2007 and 2003-2008 periods. The difference in coverage could be important because our sample includes the first two years of the great recession and the benchmark paper does not. Table 7 drops the 2002-2007 and 2003-2008 growth spells and, again, finds results that are essentially identical to our baseline estimates of Table 3. This is also the case if we drop Japan from the sample (Table 8). ${ }^{17}$

To explore whether our results are driven by outliers, we start by plotting the partial correlation between debt and growth obtained with the OLS regressions of column 1, Table 3. In Figure 5 there seem to be four influential observations: Japan 2002 and 2003 and Finland 1987 and 1988. We already discussed the case of Japan, we will soon look at Finland.

\footnotetext{
${ }^{15}$ Table 6 only reports results for $\operatorname{AR}(1)$ and $\operatorname{AR}(5)$. $\mathrm{AR}(10)$ results are available upon request.

${ }^{16}$ The flow of funds data yield higher debt ratios. The average difference between the two dataset is 12 percentage points with a standard deviation of 10 percentage points. This difference is particularly large for Australia (22 percentage point), Canada (33 percentage points), Denmark (17 percentage points), Finland (19 percentage points), France (14 percentage points), the Netherlands (15 percentage points), and Sweden (17 percentage points). The between-country standard deviation of the difference between these two sources of data is 8 percent and the within-country standard deviation is 4 percent.

${ }^{17}$ We conduct this experiment because Japan has high debt and near-zero variance in $V E$. We also looked at what happens if we drop the other four countries with near zero variance of $V E$ (France, Germany, the Netherlands and the United States) and found that the IV results are similar to those of Table 3. However, when we drop these countries, debt is no longer significantly correlated with growth in the OLS regression (the correlation remains negative, with a point estimate of -1.05 and a p-value of 0.26 ).
} 
The scatterplot of the partial correlation between debt and growth obtained with the IV regression of the third column of Table 3 (Figure 6) shows several observations which appear to be influential. Many of these observations have to do with Finland and a few with Sweden and Australia. This impression is also confirmed by the leverage plot of Figure 7 which shows that Australia 1986 and Sweden 1996 have high leverage and large residuals. We thus estimate our model by dropping Finland and the two suspect observations for Australia and Sweden.

In the OLS estimates of the reduced sample, we find the usual strong negative correlation between debt and growth (column 1, Table 10; the partial correlation is plotted in Figure 8). When we estimate the IV model we still find that the coefficient of debt is insignificant and positive (column 3, Table 10; the partial correlation is plotted in Figure 9). However, we now find that the point estimate is close to zero and not implausibly large as in the IV regression of Table 3.

\section{Non-overlapping growth spells}

As a final robustness check we look at what happens when we use non-overlapping growth spells. Given that 5-year growth spells only yield 68 observations and 46 degrees of freedom (we have ten control variables, 17 country fixed effects, and 3 period fixed effects), we also work with 3-year growth spells (119 observations and 97 degrees of freedom).

When we work with non-overlapping periods, we need to choose a starting year. Choosing the first available year, as it is usually done, appears to be arbitrary. Therefore, we estimate our model for all available starting years (1981, 1982, and 1983 when we use 3-year growth spells, and 1981, 1982, 1983, 1984, and 1985 when we use 5-year growth spells).

In the 3-year growth spells regressions, OLS estimations always find a negative and statistically significant correlation between public debt and economic growth (Column 1, top panel of Table 11). ${ }^{18}$ When we estimate the model starting in 1981, we obtain point estimates which are much larger (in absolute value) than those of the model with 5-year overlapping growth spells (-3.24 versus -1.54$)$. Instead, when the start date is set to 1982 or 1983, results obtained are closer to those of Table 3 and imply that a 10 percentage point increase in debt is associated with a 17-18 basis point decrease in growth. As before, the correlation between debt and growth disappears once we instrument debt with L.VE (Column 2, top panel of Table 11). As in the model with overlapping growth spells, we also find that IV regressions are often associated with a switch of the sign. In this case, we find a sign switch in two of our three regressions.

When we use OLS regressions for 5-year non-overlapping growth spells, we always find a negative correlation between debt and growth. The point estimates range between -0.92 and -2.08 (Column 1, bottom panel of Table 11) and are not too far from those that we obtained in Table 3. In this case, however, the coefficients are statistically significant in only 2 of our five regressions (in one of these two regressions the coefficient is only marginally significant). When we instrument public debt with $L . V E$, we no longer find a statistically significant association between debt and growth. In three of our five regressions we find that the coefficients become positive (column 2, bottom panel of Table 11). We do not want to make too much of the results of Table 11. The samples are small and the results of the first stage regressions are not encouraging. ${ }^{19}$ However, it is interesting that the regressions with non-overlapping growth spells show the same pattern as the regressions with overlapping growth spells: negative and generally

\footnotetext{
${ }^{18}$ While Table 11 only reports the coefficients for the public debt variable, the results reported there were obtained using the same specification used in Table 3 (with period fixed effects instead of year fixed effects).

${ }^{19}$ While L.VE has always the expected positive sign, the coefficient is rarely statistically significant (column 3 of Table 11). Moreover, the Kleibergen-Paap F tests of the the first stage regressions are often low (column 4 of Table 11), hinting at a serious weak instrument problem.
} 
statistically significant coefficients in the OLS regressions and insignificant and generally positive coefficients in the IV regressions.

\section{Looking for thresholds}

We now check whether there is a threshold above which public debt has a larger effect on GDP growth. In a sample of 20 advanced economies for the period 1946-2009, Reinhart and Rogoff $(2010 a, b)$ find that when public debt is above 90 percent of GDP, median growth is approximately 1 percentage point lower than in country-years with lower debt. They also show that, in high-debt countries, average growth is almost 4 percentage points lower than in countryyears in which debt is below 90 percent of GDP. Looking at histograms similar to those used by Reinhart and Rogoff, Cecchetti et al. (2011) do not find a clear correlation between different debt levels and GDP growth. They suggest that this could be due to the fact that their smaller sample requires more sophisticated econometric techniques.

They thus define $D \Psi$ as a dummy variable that takes a value of one when the debt-to-GDP ratio is below $\Psi$ and propose to estimate the following threshold regression for $\Psi \in(50,120)$.

$$
\begin{aligned}
G R O W T H_{i, t+1, t+6}= & \alpha y_{i, t}+\gamma^{\prime} X_{i, t}+\varphi D \Psi_{i, t}+\beta_{1}\left(\frac{D e b t_{i, t}}{G D P_{i, t}} D \Psi_{i, t}\right)+ \\
& +\beta_{2}\left(\frac{D e b t_{i, t}}{G D P_{i, t}}\left(1-D \Psi_{i, t}\right)\right)+\mu_{i}+\tau_{t}+\varepsilon_{i, t}
\end{aligned}
$$

Next, they compute Hansen's (1999) likelihood ratio (LR) statistics to identify the threshold that yields the best fit of Equation (7) and build confidence intervals around this threshold. ${ }^{20}$ In the case of public debt, they find that the threshold that yields the best fit of Equation (7) is 96 percent.

When we conduct the same experiment using our data, we find a pattern similar to that of Cecchetti et al. (2011) but with slightly lower values of the LR statistics (the solid line in Figure 10). In particular, we find that the threshold that yields the best fit is 92 percent of GDP with a 90 percent confidence interval of 80-98.

While these results are consistent with the presence of a threshold at around 90 percent of GDP, there are two issues with interpreting Figure 10 as evidence for the existence of such a threshold. The first has to do with the fact that Hansen's derivations assume a static model with iid errors. It is not clear whether his results apply to our model which is dynamic with heteroscedastic errors.

The second, and probably more important, issue has to do with the fact that Hansen's LR statistics cannot be used to test for the existence of a threshold. It can only be used to build a confidence interval around a threshold, under the assumption that such a threshold does exist (Hansen, 1999, p. 351). Testing for the presence of a threshold requires a more complicated bootstrapping procedure, which we will not pursue here. ${ }^{21}$

One thing that we can do is to compare the coefficients of $\beta_{1}$ and $\beta_{2}$ for different values of $\Psi$. The solid line in the top panel of Figure 11 plots the point estimates of $\beta_{1}$ (the dotted lines plot the 95 percent confidence interval) for all possible thresholds between 50 and 120 percent of GDP. It shows that the point estimates are fairly stable (they range between -1 and -2) and are

\footnotetext{
${ }^{20}$ The statistics is: $L R(\Psi)=(S(\Psi)-S(\widehat{\Psi})) / \widehat{\sigma}^{2}$. Where $S(\Psi)$ is the sum of squared errors for the model with threshold $\Psi$; $\widehat{\Psi}$ is the threshold that minimizes the sum of squared errors; and $\widehat{\sigma}^{2}$ is the variance of the error term when $\Psi=\widehat{\Psi}$.

${ }^{21}$ One reason for not doing this exercise is that we do not know the properties of Hansen's (1999) method for dynamic panels with non-iid errors.
} 
often statistically significant (they are insignificant in the 82 to 92 percent range). The bottom panel plots the values of the point estimates of $\beta_{2}$. Again, the estimates are stable (ranging from -1.5 and -2 ) and, in this case, always statistically significant.

While we find that $\beta_{2}$ is estimated more precisely than $\beta_{1}$, Figure 11 does not show a large difference between the two sets of coefficients. For instance, the point estimates suggest that debt has the same effect on GDP growth in country-years when the debt-to-GDP ratio is below 50 percent (the first observations in the top panel of Figure 10) as in country-years when the debt to GDP ratio is above 120 percent of GDP (the last observation in the bottom panel of Figure 11).

We can compute the difference between $\beta_{1}$ and $\beta_{2}$ and test whether the two parameters are significantly different from each other. The solid line in Figure 12 shows that $\beta_{1}$ tends to be larger (in absolute value) than $\beta_{2}$ when public debt is below 80 percent of GDP and that the situation reverses when debt surpasses 80 percent of GDP. The dotted line plots the p-value of a test on the difference between coefficients. It shows that this difference is rarely statistically significant. $^{22}$ While this is not a true test for the presence of a threshold, Figure 12 provides suggestive evidence that such a threshold may not exist.

Reinhart and Rogoff (2010a) argue that it is hard to find instruments in the presence of thresholds. We tend to agree with them, but we try anyway. With one threshold, we have two endogenous variables and we need two instruments. In principle, if $L . V E$ is a good instrument for Debt, $L . V E * D \Psi$ could be an instrument for $D E B T * D \Psi$, and $L . V E *(1-D \Psi)$ could be an instrument for $D E B T *(1-D \Psi)$. The problem is that these instruments may not be powerful enough to identify the effect of debt on growth.

When we compute Hansen's (1999) LR statistics using IV estimates, we find an almost flat line (the dashed line in Figure 10). This could be due to the fact that the statistics is meaningless in the presence of IV estimates; it could also be a sign that the confidence interval for the threshold is very large (and therefore there is no threshold); or that there are problems with our IV strategy.

Figure 13 plots the values of $\beta_{1}$ and $\beta_{2}$ obtained with the IV estimates. They are unstable, suggesting that our instrument does not work well in the threshold regression of Equation (7). To probe further, we look in detail at the threshold regression with $\Psi=90$. The first column of Table 12 reports the OLS estimates (they correspond to the coefficients plotted in Figure 1 when the threshold is 90). We find that the debt-to-GDP ratio has a negative, but not statistically significant, effect on growth when debt is lower than 90 percent of GDP, and that the debt-toGDP ratio has a larger (in absolute value) and statistically significant effect on growth when debt is greater than 90 percent of GDP. The difference between the two coefficients, however, is not statistically significant (Figure 12).

The second and third columns of Table 12 report the first stage estimates. One of the two instruments has some power in column 2 , but the instruments have no power whatsoever in column 3. The underidentification and weak instrument tests reported in the bottom panel of the Table confirm that our model is underidentified (the rank condition is not satisfied) and that the instruments are weak. For sake of completeness, we report the second stage estimates. However, we believe that these estimates are completely unreliable. We report Table 12 to be fully transparent and make the point that in the threshold regression of Equation (7) our instrument is useless. This is why the point estimates of Figure 13 are so unstable.

The first stage regressions of Table 12 indicate that our instrument works better for low levels

\footnotetext{
${ }^{22}$ The p-value is less than 0.05 in 6 of our 70 observations (when the threshold is $84,85,86,89$, and 93). Note that if our 120 observations were the outcome of independent trials (which they are not), we would have expected to find 3.5 observations with a p-value smaller than 0.05 , even in the absence of any true difference between the two coefficients.
} 
of debt. Therefore, we try splitting the sample. ${ }^{23}$ Again, we start with the OLS regression. In the low debt sample, we find a negative but not statistically significant correlation between debt and growth (column 1 of Table 13). In the first stage regression of column 2, our instrument has the right sign but is not statistically significant. The underidentification tests shows that our instrument satisfies the rank condition, but the $\mathrm{F}$ test indicates that the instrument could be weak (recall, however, that in an exactly identified model like ours the presence of a weak instrument may not be such a big problem, Angrist and Pischke (2009)). The IV regression of column 3 finds that debt is now positive and insignificant. In columns 4-6 we try to gain degrees of freedom by re-estimating the model without controls. The results are qualitatively similar to those of columns 1-3.

In Table 14, we repeat the experiment of Table 13 by focusing on the country-years for which debt is above 90 percent of GDP. As expected, we find that the instrument is weak and that the results of the IV estimates are meaningless.

One surprising finding of Table 14 is that the coefficient is not even statistically significant in the OLS regression (column 1). This may be due to the fact that the regression does not have enough degrees of freedom (with 90 observations, 8 country fixed effects, 22 year fixed effects, and 12 control variables, the regression has 48 degrees of freedom) or due to the fact that our sample is not poolable (i.e., the other controls have different effects on growth in low and high-debt countries). Column 4 shows that if we try to save degrees of freedom by dropping our set of controls, the coefficient of public debt goes back to values similar to those of Tables 2 and 3 and becomes statistically significant at the 10 percent confidence level.

\section{An alternative identification strategy}

As our instrument does not perform well in high debt countries, we now experiment with an alternative identification strategy. Let us go back to our simple model of Equations (1) and (2), but let us now assume that we have an instrument for GDP growth:

$$
\begin{gathered}
G=a+b D+\gamma T P G R O W T H+u \\
D=m+k G+v
\end{gathered}
$$

Since TPGROWTH does not belong in the debt equation, we can identify the effect of growth on debt (the structural parameter $k$ ). Without additional assumptions, we cannot estimate $b$ which is our structural parameter of interest.

However, Fisher (1966) showed that if $u$ and $v$ are true structural shocks (i.e., if $E(u, v)=0$ ) a model like that of Equations (8) and (9) has enough restrictions to identify both $k$ and $b$. He called this identification method, identification through covariance restrictions. Hausman and Taylor (1983) showed that identification through covariance restrictions has an instrumental variable interpretation, and Hausman, Newey and Taylor (1987) proposed an augmented three stages least squares (a3SLS) estimator for simultaneous equations with covariance restrictions.

This method is rarely used because the implementation of the a3SLS estimator is cumbersome. However, Shapiro (1987) shows that, in an exactly identified two equations system like that of Equations (8) and (9), the implementation of the a3SLS estimator consist of four straightforward steps analogous to two 2SLS. The first step (the first stage of the first 2SLS) consists of regressing $G$ over TPGROWTH (and any other exogenous regressor that belongs to

\footnotetext{
${ }^{23}$ By splitting the sample, we relax the assumption that the effect of the controls is the same in low and high-debt countries. If this assumption were true, split-sample regressions would be unbiased but inefficient. If this assumption does not hold, split sample regressions are only unbiased.
} 
both equations) and then recovering $\widehat{G}$. In the second step (the second stage of the first 2SLS), we estimate $k$ by regressing $D$ over $\widehat{G}$ (and other exogenous regressors) and then recover $\widehat{v}$. By construction, $\widehat{v}$ is correlated with $D$ and, by assumption, uncorrelated with $G$. We can then use $\widehat{v}$ as an instrument for $D$. Therefore, in the third step (the first stage of the second 2SLS) we regress $D$ over $\widehat{v}$ and other exogenous regressors and recover $\widehat{D}$. In the fourth step (the second stage of the second 2SLS), we estimate $b$ (the structural parameter of interest) by regressing $G$ over $\widehat{D}^{24}$

Therefore, if we were to assume that $u$ and $v$ are true structural shocks and could find an instrument for growth, we would have an alternative way to identify the effect of debt on growth. Panizza and Jaimovich (2007) show that a real external shock consisting of the weighted average of GDP growth in a country's export partners is a good instrument for annual GDP growth. They define the real external shock as:

$$
J P_{i, t}=\frac{E X P_{i}}{G D P_{i}} \sum \phi_{i j, t-1} G D P G R O W T H_{j, t},
$$

where GDPGROWT $H_{j, t}$ measures real GDP growth in country $j$ in period $t, \phi_{i j, t}$ is the fraction of exports from country $i$ going to country $j$, and $E X P_{i} / G D P_{i}$ measures country's $i$ average exports expressed as a share of GDP. ${ }^{25}$

The JP instrument is a refinement on the instrument used by Galì and Perotti (2003) in a paper that studies fiscal cyclicality in the Euro area. Variants of the JP instrument have been used by Alesina, Campante and Tabellini (2008), Ilzetzki and Végh (2008), and Végh and Vuletin (2012). Panizza and Jaimovich (2007) discuss in detail the properties of this instrument.

While there is evidence that the JP instrument works well at the annual frequency, the instrument has not yet been used at lower frequencies. Therefore, we start by building a variable TPGROWTH which is equal to $J P_{(t+6, t+1)}$ and then run a set of (first) first stage regressions to check whether TPGROWTH is a good instrument for growth over five-year periods. When we estimate the model for the whole sample, the results are not encouraging (column 1, top panel of Table 15). ${ }^{26}$ TPGROWTH is not statistically significant and fails all the underidentification and weak instrument tests reported in the first column of Table 14.

When we estimate the first stage for the subsample of country-years with debt below 90 percent of GDP, we find that the coefficient of TPGROWTH is statistically significant at the ten percent confidence level and that the tests reject underidentification (Column 2, top panel of Table 15). The F test is still low, but much higher than that of Column 1. However, $T P G R O W T H$ has the wrong sign. The point estimate suggests that high trading partner growth reduces country $i$ 's growth. This cannot be right.

Things improve when we look at high-debt observations (columns 3 and 4 of the top panel of Table 15). In country-years with debt-to-GDP ratios above 0.9 (column 3), we find a positive and statistically significant impact of trading partner growth, good underidentification tests, and an acceptable (albeit still low) first stage $\mathrm{F}$ statistic. ${ }^{27}$

\footnotetext{
${ }^{24} \mathrm{As}$ the instrument of the second 2SLS is an estimated parameter, we need to adjust the standard errors of the second 2SLS. Shapiro (1987) describes how to do it.

${ }^{25}$ They use a time invariant measure of exports over GDP because a time variant measure would be affected by real exchange rate fluctuations, and, therefore, by domestic factors. This is not the case for the fraction of exports going to a specific country $\left(\phi_{i j, t}\right)$, because the variation of the exchange rate that is due to domestic factors has an equal effect in both the numerator and denominator. We build the JP instrument for the sample of 17 OECD countries using the bilateral trade data published in the Correlates of War Project's Trade Data Set (Barbieri, Keshk and Pollins, 2012, 2009), which is based on the IMF Directions of Trade Statistics.

${ }^{26}$ Note that the estimations of Table 15 include all the controls used in Table 2. The coefficients are not reported to save space.

${ }^{27}$ In fact, we do not know the critical values of these tests for the a3SLS estimator.
} 
One problem with restricting the sample to country-years with debt above 90 percent of GDP is that we only have 90 observations. We also experiment with an 80 percent threshold (119 observations) and still find that the instrument has a positive and statistically significant effect on growth (column 4). The underidentification and weak instrument tests are worse than those of column 3 but still acceptable according to the Angrist and Pischke (2009) criterion. When we include observations with debt levels below 80 percent of GDP, our instrument no longer works.

On the basis of the results of the top panel of Table 15, we apply Hausman, Newey and Taylor's (1987) a3SLS estimator to the subsamples of country-years with debt above 80 and 90 percent of GDP. In the first column of the bottom panel of Table 15, we report the OLS estimates for the above 90 percent of GDP subsample. As in Table 14, the coefficient is negative but not statistically significant. ${ }^{28}$ The a3SLS estimator, instead, finds a positive and statistically significant coefficient. We do not want to make too much of the fact that the coefficient is statistically significant. But we want to highlight that the results of this alternative estimation strategy are fully consistent with what we found in the regressions of Tables 2 and 3. While OLS regressions yield a negative correlation between debt and growth, instrumental variables regressions find the opposite.

In the last two columns of the bottom panel of Table 15, we expand our sample to include countries with a debt-to-GDP ratio of at least 0.8. The OLS regression finds a negative and statistically significant correlation between debt and growth (column 3) and, again, the a3SLS estimator finds a positive (this time insignificant) effect.

Finding a good instrument is always difficult and we agree with Reinhart and Rogoff (2010a) that finding instruments in the presence of thresholds is particularly hard. However, we found that in our subsample of countries the evidence of a threshold effect is not as strong as previously thought. Moreover, we have an instrument that has some power in the subsample of low-debt countries and an alternative identification strategy that works in the high-debt subsample, and we show that both identification strategies suggest that there is no evidence that debt has a causal effect on economic growth.

\title{
6 Conclusions
}

\begin{abstract}
It ain't what you don't know that gets you into trouble. It's what you know for sure that just ain't so
\end{abstract}

(attributed to Mark Twain)

We started this paper with a question. What did we find? Does debt have a causal effect on economic growth? Unfortunately, our answer to this question is: "We don't know".

We are well-aware that "we don't know" papers are not as satisfying as papers with a clear result. However, we think that there is some value in assessing the degree of our ignorance (see the Mark Twain quote at the beginning of this section).

We believe that our findings are important for the current debate on fiscal policy. There might be many good (or bad) reasons for fiscal austerity, even during recessions. We do not want to enter that debate here. However, we do not find any evidence that high public debt

\footnotetext{
${ }^{28}$ This regression is similar to that reported in column 1 of Table 14 . The only difference is that the regression of Table 15 does not control for the effective exchange rate and foreign currency share. Again, the regressions of Table 15 include all the controls used in Table 2, but only report the coefficient of the variable of interest.
} 
levels hurt future growth in advanced economies. ${ }^{29}$ Therefore, given the state of our current knowledge, we think that the debt-growth link should not be used as an argument in support of fiscal consolidation.

We recognize that instruments are never perfect and that their use involves tradeoffs between consistency and efficiency. In describing the strengths and weaknesses of our identification strategy, we tried to be as transparent as possible and conducted extensive robustness checks. Among other things, we used a new Bayesian approach to check what happens if we relax our exclusion restriction and experimented with the a3SLS estimator of Hausman, Newey and Taylor (1987). Nevertheless, our exclusion restrictions are non-testable, and we may never be able to convince skeptical readers of their validity. Yet, we are convinced that our instrument is valid and strong and we were reassured by the fact that the instrumental variable results are consistent with theoretical arguments suggesting that OLS estimations are negatively biased. Our confidence was also bolstered by the finding that two completely different identification strategies yield similar results.

The fact that we do not find a negative effect of debt on growth does not mean that countries can sustain any level of debt. There is clearly a level of debt which is unsustainable (for instance, when the interest bill becomes greater than GDP) and a debt-to-GDP ratio at which debt overhang, with all its distortionary effects, kicks in. What our results seem to indicate, however, is that the advanced economies in our sample are still below the country-specific threshold at which debt starts having a negative effect on growth.

We believe that there is a subtle channel, which may not be captured in our empirical exercise, through which high levels of public debt can have a negative effect on growth. ${ }^{30}$ In the presence of multiple equilibria, a fully solvent government with a high level of debt may decide to put in place restrictive fiscal policies to reduce the probability that a sudden change in investors' sentiments would push the country towards the bad equilibrium. ${ }^{31}$ These policies, in turn, may reduce growth (Perotti, 2012), especially if implemented during a recession. ${ }^{32}$ In this case, it would be true that debt reduces growth, but only because high levels of debt lead to contractionary policies. While such an interpretation would justify long-term policies aimed at reducing debt levels, it also implies that countries should not implement restrictive policies in the middle of a crisis. These policies are the reason for the negative effect of debt on growth. Of course, policymakers under pressure from market participants might not have an alternative. This is why we need prudent fiscal policies and lenders of last resort that can rule out multiple equilibria.

In fact, we suspect that we do not find a negative effect of debt on growth because most of the observations included in our dataset are for years in which all OECD countries could use their own central banks as lenders of last resort. With the creation of the euro, however, about half of the countries in our sample lost their lender of last resort and soon started facing market pressure (De Grauwe, 2011).

Our readings of the current empirical evidence linking public debt and economic growth in advanced economies can be summarized as follows: (i) many papers show that public debt is

\footnotetext{
${ }^{29}$ Things are different in developing countries, where a significant fraction of debt is external and the debt overhang argument (Krugman, 1988; Sachs, 1989) has more bite. For evidence in this direction see Cordella, Ricci and Ruiz-Arranz (2010) and Pattillo, Poirson and Ricci (2011).

${ }^{30}$ We would like to thank, without implications, Carlo Cottarelli for suggesting this point.

${ }^{31}$ Alternatively, policy makers may decide to implement these restrictive policies as a reaction to market signals which do not reflect the true fundamentals (we started from the assumption that the government is solvent).

${ }^{32}$ DeLong and Summers (2012) discuss the conditions under which the recessionary effect would be so large that the contractionary policy would actually be self-defeating and lead to a higher debt-to-GDP ratio. In its massive downgrade of European sovereigns in January 2012, Standard and Poor's explicitly mentioned that restrictive policies may have a negative effect on debt sustainability (Standard \& Poor's, 2012).
} 
negatively correlated with economic growth; (ii) no paper makes a convincing case for a causal link between debt and growth; (iii) our paper suggests that such a causal link does not exist (more precisely, our paper does not reject the null hypothesis that debt has no impact on growth). We realize that our results are controversial, and that some readers will not be convinced by our identifications strategy. However, we also believe that the first two points are uncontroversial, and the case that debt has causal effect on growth still needs to be made. 


\section{References}

Alesina, Alberto, Filipe R. Campante and Guido Tabellini. 2008. "Why is Fiscal Policy Often Procyclical?" Journal of the European Economic Association 6(5):1006-1036.

Angrist, Joshua D. and Jorn-Steffen Pischke. 2009. "A Note on Bias in Just Identified IV with Weak Instruments." London School of Economics.

Arellano, Manuel and Olympia Bover. 1995. "Another look at the instrumental variable estimation of error-components models." Journal of Econometrics 68(1):29-51.

Arellano, Manuel and Stephen Bond. 1991. "Some Tests of Specification for Panel Data: Monte Carlo Evidence and an Application to Employment Equations." Review of Economic Studies 58(2):277-97.

Barbieri, Katherine, Omar Keshk and Brian Pollins. 2009. "Trading Data: Evaluating our Assumptions and Coding Rules." Conflict Management and Peace Science 26(5):471-491.

Barbieri, Katherine, Omar Keshk and Brian Pollins. 2012. "Correlates of War Project Trade Data Set Codebook, Version 3.0." Online: http://correlatesofwar.org.

Bekaert, Geert, Campbell R. Harvey and Christian Lundblad. 2001. "Emerging equity markets and economic development." Journal of Development Economics 66(2):465-504.

Bekaert, Geert, Campbell R. Harvey and Christian Lundblad. 2005. "Does financial liberalization spur growth?" Journal of Financial Economics 77(1):3-55.

Blundell, Richard and Stephen Bond. 1998. "Initial conditions and moment restrictions in dynamic panel data models." Journal of Econometrics 87(1):115-143.

Bond, Stephen Roy. 2002. "Dynamic panel data models: a guide to micro data methods and practice." Portuguese Economic Journal 1:141-162.

Bound, John, David A Jaeger and Regina M Baker. 1995. "Problems with Instrumental Variables Estimation When the Correlation between the Instruments and the Endogenous Explanatory Variables is Weak." Journal of the American Statistical Association 90(430):443-450.

Cafiso, Gianluca and Roberto Cellini. 2012. "Evidence on Fiscal Consolidations and the Evolution of Public Debt in Europe." University of Catania.

Cecchetti, Stephen, Madhusudan Mohanty and Fabrizio Zampolli. 2011. The real effects of debt. BIS Working Papers 352 Bank for International Settlements.

Checherita, Cristina and Philipp Rother. 2010. The impact of high and growing government debt on economic growth: an empirical investigation for the euro area. Working Paper Series 1237 European Central Bank.

Cordella, Tito, Luca Antonio Ricci and Marta Ruiz-Arranz. 2010. "Debt Overhang or Debt Irrelevance?" IMF Staff Papers 57(1):1-24.

Cottarelli, Carlo. 2011. "The Risk Octagon: A Comprehensive Framework For Assessing Sovereign Risks." http://www.imf.org/external/np/fad/news/2011/docs/Cottarelli1.pdf.

Cottrell, Allin and Riccardo Lucchetti. $2012 . \quad$ "Gretl User's Guide." http://sourceforge.net/projects/gretl/files/manual/gretl-guide.pdf/download. 
De Grauwe, Paul. 2011. The Governance of a Fragile Eurozone. Working Document 346 CEPS.

DeLong, Bradford J and Lawrence H Summers. 2012. "Fiscal Policy in a Depressed Economy." The Brookings Institution.

Eichengreen, Barry J., Ricardo Hausmann and Ugo Panizza. 2005. The Pain of Original Sin. In Other People's Money: Debt Denomination and Financial Instability in Emerging-Market Economies, ed. Barry J. Eichengreen and Ricardo Hausmann. University Of Chicago Press chapter 1.

Fisher, Franklin M. 1966. The Identification Problem in Econometrics. McGraw-Hill.

Galì, Jordi and Roberto Perotti. 2003. "Fiscal policy and monetary integration in Europe." Economic Policy 18(37):533-572.

Gros, Daniel. 2011. "Can Austerity be self-defeating." VoxEU.org.

Hansen, Bruce E. 1999. "Threshold effects in non-dynamic panels: Estimation, testing, and inference." Journal of Econometrics 93(2):345-368.

Hausman, Jerry A, Whitney K Newey and William E Taylor. 1987. "Efficient Estimation and Identification of Simultaneous Equation Models with Covariance Restrictions." Econometrica 55(4):849-74.

Hausman, Jerry A and William E Taylor. 1983. "Identification in Linear Simultaneous Equations Models with Covariance Restrictions: An Instrumental Variables Interpretation." Econometrica 51(5):1527-49.

Hausmann, Ricardo and Ugo Panizza. 2011. "Redemption or Abstinence? Original Sin, Currency Mismatches and Counter Cyclical Policies in the New Millennium." Journal of Globalization and Development 2(1):4.

Hausmann, Ricardo, Ugo Panizza and Roberto Rigobon. 2006. "The long-run volatility puzzle of the real exchange rate." Journal of International Money and Finance 25(1):93-124.

Ilzetzki, Ethan and Carlos A. Végh. 2008. Procyclical Fiscal Policy in Developing Countries: Truth or Fiction? NBER Working Papers 14191 National Bureau of Economic Research, Inc.

Kraay, Aart. 2012. "Instrumental Variables Regressions with Uncertain Exclusion Restrictions: A Bayesian Approach." Journal of Applied Econometrics 27(1):108-128.

Krugman, Paul. 1988. "Financing vs. forgiving a debt overhang." Journal of Development Economics 29(3):253-268.

Krugman, Paul. 2011. "Self-defeating Austerity." New York Times, July 7.

Kumar, Manmohan S. and Jaejoon Woo. 2010. Public Debt and Growth. IMF Working Papers 10/174 International Monetary Fund.

Missale, Alessandro. 1999. Public Debt Management. Oxford: Oxford University Press.

Moreira, Marcelo J. 2003. "A Conditional Likelihood Ratio Test for Structural Models." Econometrica 71(4):1027-1048. 
Mussa, Michael. 1986. "Nominal exchange rate regimes and the behavior of real exchange rates: Evidence and implications." Carnegie-Rochester Conference Series on Public Policy 25(1):117214.

Newey, Whitney K and Kenneth D West. 1987. "A Simple, Positive Semi-definite, Heteroskedasticity and Autocorrelation Consistent Covariance Matrix." Econometrica 55(3):703-708.

Panizza, Ugo. 2008. Domestic And External Public Debt In Developing Countries. UNCTAD Discussion Papers 188 United Nations Conference on Trade and Development.

Panizza, Ugo and Dany Jaimovich. 2007. Procyclicality or Reverse Causality? RES Working Papers 4508 Inter-American Development Bank, Research Department.

Pattillo, Catherine A., Helene Poirson and Luca Antonio Ricci. 2011. "External Debt and Growth." Review of Economics and Institutions 2(3).

Perotti, Roberto. 2012. The "Austerity Myth" Gain Without Pain? In Fiscal Policy after the Financial Crisis. NBER Chapters National Bureau of Economic Research, Inc.

Powell, Andrew. 2012. The World of Forking Paths - Latin America and the Caribbean Facing Global Economic Risks. Washington, DC: Inter-American Development Bank.

Presbitero, Andrea F. 2012. "Total Public Debt and Growth in Developing Countries." European Journal of Development Research forthcoming.

Reinhart, Carmen M. and Kenneth S. Rogoff. 2009. This Time is Different - Eight Centuries of Financial Folly. Princeton, New Jersey: Princeton University Press.

Reinhart, Carmen M. and Kenneth S. Rogoff. 2010a. "Debt and Growth Revisited." VoxEU.org.

Reinhart, Carmen M. and Kenneth S. Rogoff. 2010b. "Growth in a Time of Debt." American Economic Review 100(2):573-78.

Rodrik, Dani. 2008. "The Real Exchange Rate and Economic Growth." Brookings Papers on Economic Activity 39(2 (Fall)):365-439.

Sachs, Jeffrey D. 1989. The Debt Overhang of Developing Countries. In Debt, Stabilization and Development, ed. Guillermo A. Calvo, Ronald Findlay, Pentti Kouri and Jorge Braga de Macedo. Oxford: Basil Blackwell.

Shapiro, Matthew D. 1987. Measuring Market Power in U.S Industry. Technical Report 828 Cowles Foundation Discussion Paper.

Staiger, Douglas and James H. Stock. 1997. "Instrumental Variables Regression with Weak Instruments." Econometrica 65(3):557-586.

Standard \& Poor's. 2012. Standard \& Poor's Takes Various Rating Actions On 16 Eurozone Sovereign Governments. Ratingsdirect on the global direct portal Standard \& Poor's.

Stock, James H. and Motohiro Yogo. 2005. Testing for Weak Instruments in Linear IV Regression. In Identification and Inference for Econometric Models: Essays in Honor of Thomas Rothenberg, ed. Donald W.K. Andrews and James H. Stock. Cambridge University Press chapter 5, pp. 80-108. 
Sutherland, Douglas, Peter Hoeller and Rossana Merola. 2012. Fiscal consolidation: Part 1. How much is needed and how to reduce debt to a prudent level? OECD Economics Department Working Papers 932 OECD.

UNCTAD. 2011. Trade and Development Report 2011. Technical report United Nations.

Végh, Carlos A. and Guillermo Vuletin. 2012. How is Tax Policy Conducted over the Business Cycle? NBER Working Papers 17753 National Bureau of Economic Research, Inc. 


\section{A Tables}

Table 1: Country-by-Country Summary Statistics for $V E$

\begin{tabular}{lccccc}
\hline & Mean & Std. Dev. & Min & Max & N. Obs \\
\hline AUS & $0.69 \%$ & $1.57 \%$ & $-1.03 \%$ & $5.37 \%$ & 28 \\
AUT & $-0.01 \%$ & $0.60 \%$ & $-1.49 \%$ & $1.43 \%$ & 28 \\
BEL & $0.13 \%$ & $0.93 \%$ & $-1.93 \%$ & $2.98 \%$ & 28 \\
CAN & $0.02 \%$ & $0.43 \%$ & $-0.85 \%$ & $0.70 \%$ & 28 \\
DEU & $0.00 \%$ & $0.01 \%$ & $-0.04 \%$ & $0.04 \%$ & 28 \\
DNK & $0.30 \%$ & $1.21 \%$ & $-1.98 \%$ & $3.61 \%$ & 28 \\
ESP & $0.15 \%$ & $0.51 \%$ & $-0.45 \%$ & $1.89 \%$ & 28 \\
FIN & $0.84 \%$ & $1.25 \%$ & $-2.68 \%$ & $6.51 \%$ & 28 \\
FRA & $0.00 \%$ & $0.00 \%$ & $0.00 \%$ & $0.00 \%$ & 28 \\
GBR & $0.04 \%$ & $0.15 \%$ & $-0.28 \%$ & $0.52 \%$ & 28 \\
ITA & $-0.02 \%$ & $0.23 \%$ & $-0.64 \%$ & $0.46 \%$ & 28 \\
JPN & $0.00 \%$ & $0.01 \%$ & $-0.02 \%$ & $0.01 \%$ & 28 \\
NLD & $0.00 \%$ & $0.02 \%$ & $0.00 \%$ & $0.01 \%$ & 28 \\
NOR & $0.23 \%$ & $0.75 \%$ & $-0.65 \%$ & $3.02 \%$ & 28 \\
PRT & $0.04 \%$ & $0.44 \%$ & $-0.68 \%$ & $1.16 \%$ & 16 \\
SWE & $0.43 \%$ & $1.89 \%$ & $-3.41 \%$ & $7.50 \%$ & 28 \\
USA & $0.00 \%$ & $0.00 \%$ & $0.00 \%$ & $0.00 \%$ & 28 \\
\hline Total & $0.17 \%$ & $0.97 \%$ & $-3.41 \%$ & $7.50 \%$ & 464 \\
\hline
\end{tabular}

Notes: Data for Portugal start in 1993. We report VE in percentage term to enhance readability. In the regressions, VE is used in levels. 
Table 2: Baseline regressions

\begin{tabular}{|c|c|c|c|}
\hline & (1) & $(2)$ & (3) \\
\hline & OLS & \multicolumn{2}{|c|}{ Instrumental Variable Estimates } \\
\hline & & First Stage & IV \\
\hline Debt/GDP & $\begin{array}{l}-1.796^{* * *} \\
(0.588)\end{array}$ & & $\begin{array}{l}0.322 \\
(3.647)\end{array}$ \\
\hline Log Initial GDP PC & $\begin{array}{l}-20.61^{* * *} \\
(2.708)\end{array}$ & $\begin{array}{l}-1.851^{* *} \\
(0.734)\end{array}$ & $\begin{array}{l}-16.62^{* *} \\
(6.605)\end{array}$ \\
\hline National Gross Savings & $\begin{array}{l}0.022 \\
(0.029)\end{array}$ & $\begin{array}{l}-0.004 \\
(0.009)\end{array}$ & $\begin{array}{l}0.032 \\
(0.034)\end{array}$ \\
\hline Population Growth & $\begin{array}{l}3.630 \\
(31.190)\end{array}$ & $\begin{array}{l}-3.218 \\
(5.542)\end{array}$ & $\begin{array}{l}10.440 \\
(40.450)\end{array}$ \\
\hline Schooling & $\begin{array}{l}0.710^{* * *} \\
(0.179)\end{array}$ & $\begin{array}{l}0.013 \\
(0.031)\end{array}$ & $\begin{array}{l}0.682^{* * *} \\
(0.186)\end{array}$ \\
\hline Trade openness & $\begin{array}{l}0.0200^{*} \\
(0.011)\end{array}$ & $\begin{array}{l}-0.001 \\
(0.005)\end{array}$ & $\begin{array}{l}0.022 \\
(0.014)\end{array}$ \\
\hline Inflation rate & $\begin{array}{l}0.028 \\
(0.033)\end{array}$ & $\begin{array}{l}-0.0108^{*} \\
(0.006)\end{array}$ & $\begin{array}{l}0.048 \\
(0.053)\end{array}$ \\
\hline Dependency ratio & $\begin{array}{l}-0.158^{* * *} \\
(0.047)\end{array}$ & $\begin{array}{l}-0.008 \\
(0.015)\end{array}$ & $\begin{array}{l}-0.140^{* * *} \\
(0.051)\end{array}$ \\
\hline Banking Crisis & $\begin{array}{l}-0.025 \\
(0.232)\end{array}$ & $\begin{array}{l}-0.008 \\
(0.026)\end{array}$ & $\begin{array}{l}-0.013 \\
(0.218)\end{array}$ \\
\hline Liquid liabilities/GDP & $\begin{array}{l}0.476 \\
(0.358)\end{array}$ & $\begin{array}{l}0.050 \\
(0.072)\end{array}$ & $\begin{array}{l}0.377 \\
(0.490)\end{array}$ \\
\hline L.VE & & \multicolumn{2}{|l|}{$\begin{array}{l}1.594^{* * *} \\
(0.525)\end{array}$} \\
\hline N. Obs. & 362 & 362 & 362 \\
\hline R-squared & 0.694 & 0.307 & 0.435 \\
\hline \multirow[t]{2}{*}{ N. of countries } & 17 & 17 & 17 \\
\hline & & \multicolumn{2}{|c|}{ Underidentification and weak instrument tests } \\
\hline $\begin{array}{l}\text { K-P LM Stat. } \\
\text { p-value } \\
\text { K-P Wald Stat. } \\
\text { p-value } \\
\text { K-P F test }\end{array}$ & & $\begin{array}{l}\text { TSLS 95\% } \\
\text { CLRT 95\% }\end{array}$ & $\begin{array}{l}2 \\
56 \\
68 \\
01 \\
1 \\
\text { aterval for Debt/GDP } \\
7.4] \\
\text { nterval for Debt/GDP } \\
19.39]\end{array}$ \\
\hline
\end{tabular}

Notes: The table reports the regression coefficients and, in brackets, the associated robust (Hubert-White sandwich correction) standard errors. ${ }^{*}$ significant at $10 \% ; * *$ significant at $5 \% ; * * *$ significant at $1 \%$. 
Table 3: Baseline regressions, controlling for foreign currency share and effective exchange rate

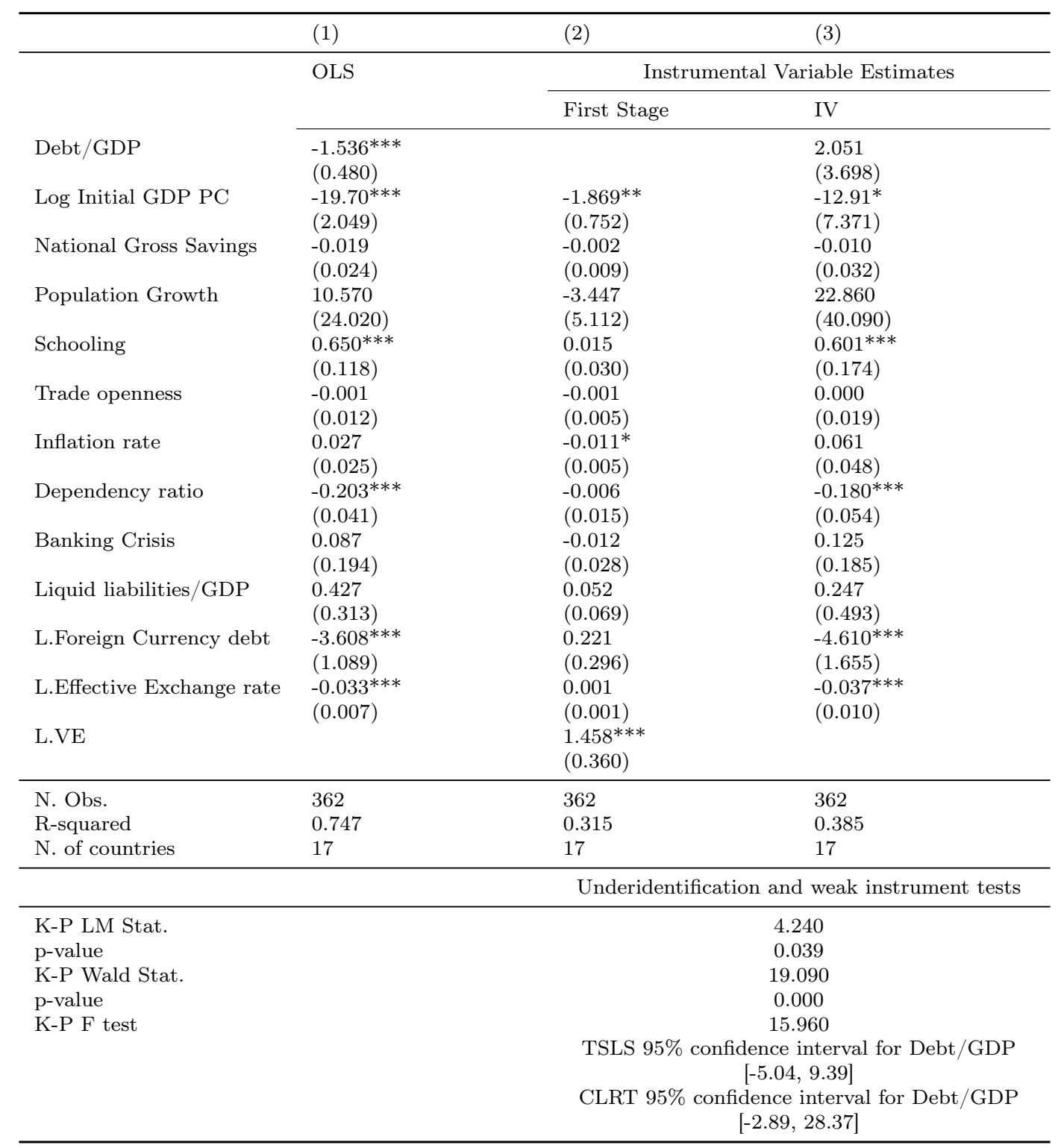

Notes: The table reports the regression coefficients and, in brackets, the associated robust (Hubert-White sandwich correction) standard errors. ${ }^{*}$ significant at $10 \% ;{ }^{* *}$ significant at $5 \%$; ** significant at $1 \%$. 
Table 4: The consequences of weak exclusion restrictions

\begin{tabular}{lcccccc}
\hline & \multicolumn{2}{c}{$\begin{array}{c}\text { Model that does not control for foreign currency } \\
\text { share and debt composition (Table 2) }\end{array}$} & \multicolumn{2}{c}{$\begin{array}{c}\text { Model that controls for foreign currency } \\
\text { share and debt composition (Table 3) }\end{array}$} \\
\cline { 2 - 7 }$\eta$ & Median & \multicolumn{2}{c}{$95 \%$ confidence interval } & Median & $95 \%$ confidence interval \\
\hline 5 & 0.41 & -42.22 & 48.17 & 2.06 & -43.93 & 59.89 \\
10 & 0.30 & -30.32 & 35.58 & 1.96 & -30.96 & 45.65 \\
100 & 0.30 & -9.91 & 15.9 & 1.96 & -8.37 & 23.42 \\
200 & 0.30 & -7.69 & 13.66 & 1.97 & -6.06 & 21.41 \\
500 & 0.33 & -6.13 & 12.49 & 1.99 & -4.47 & 20.86 \\
999 & 0.29 & -5.01 & 10.88 & 1.96 & -3.24 & 19.21 \\
\hline Standard IV & 0.32 & -6.83 & 7.47 & 2.05 & -3.83 & 7.93 \\
\hline
\end{tabular}

Notes: Results are estimated using GRETL (Cottrell and Lucchetti, 2012).

Table 5: Placebo regressions

\begin{tabular}{lcc}
\hline & $(1)$ & $(2)$ \\
\hline mean & -1.50 & -2.50 \\
Standard deviation of the mean & 24.60 & 20.09 \\
$5^{t h}$ percentile & -28.63 & -25.52 \\
median & -1.59 & -1.82 \\
$95^{t h}$ percentile & 29.17 & 21.46 \\
\hline Model & Column 3, Table 2 & Column 3, Table 3 \\
\hline
\end{tabular}

Notes: This table shows the distribution of the estimated coefficients of public debt in 1,000 replications of the regressions of Tables 2 and 3 (column 3) where L.VE was substituted with a randomly generated variable with the same mean and variance of L.VE. 
Table 6: Regressions with Newey-West standard errors

\begin{tabular}{|c|c|c|c|c|c|c|}
\hline & (1) & (2) & (3) & (4) & (5) & (6) \\
\hline & \multicolumn{3}{|c|}{ Errors have AR(1) structure } & \multicolumn{3}{|c|}{ Errors have AR(5) structure } \\
\hline & OLS & First Stage & IV & OLS & First Stage & IV \\
\hline Debt/GDP & $\begin{array}{c}-1.536^{* * *} \\
(0.342)\end{array}$ & & $\begin{array}{c}2.051 \\
(3.840)\end{array}$ & $\begin{array}{c}-1.536^{* * *} \\
(0.396)\end{array}$ & & $\begin{array}{c}2.051 \\
(3.805)\end{array}$ \\
\hline Log Initial GDP PC & $\begin{array}{c}-19.700^{* * *} \\
(1.709)\end{array}$ & $\begin{array}{c}-1.869^{* * *} \\
(0.363)\end{array}$ & $\begin{array}{c}-12.910^{*} \\
(7.383)\end{array}$ & $\begin{array}{c}-19.700^{* * *} \\
(1.910)\end{array}$ & $\begin{array}{c}-1.869^{* * *} \\
(0.489)\end{array}$ & $\begin{array}{c}-12.910^{*} \\
(7.389)\end{array}$ \\
\hline National Gross Savings & $\begin{array}{l}-0.019 \\
(0.020)\end{array}$ & $\begin{array}{l}-0.002 \\
(0.005)\end{array}$ & $\begin{array}{l}-0.010 \\
(0.025)\end{array}$ & $\begin{array}{l}-0.019 \\
(0.022)\end{array}$ & $\begin{array}{l}-0.002 \\
(0.007)\end{array}$ & $\begin{array}{l}-0.010 \\
(0.028)\end{array}$ \\
\hline Population Growth & $\begin{array}{c}10.570 \\
(16.990)\end{array}$ & $\begin{array}{l}-3.447 \\
(4.037)\end{array}$ & $\begin{array}{c}22.860 \\
(29.030)\end{array}$ & $\begin{array}{c}10.570 \\
(20.130)\end{array}$ & $\begin{array}{l}-3.447 \\
(4.912)\end{array}$ & $\begin{array}{c}22.860 \\
(34.380)\end{array}$ \\
\hline Schooling & $\begin{array}{c}0.650^{* * *} * \\
(0.151)\end{array}$ & $\begin{array}{c}0.015 \\
(0.019)\end{array}$ & $\begin{array}{c}0.601^{* * *} * \\
(0.172)\end{array}$ & $\begin{array}{c}0.650^{* * *} * \\
(0.152)\end{array}$ & $\begin{array}{c}0.015 \\
(0.024)\end{array}$ & $\begin{array}{c}0.601^{* * *} * \\
(0.184)\end{array}$ \\
\hline Trade openness & $\begin{array}{l}-0.001 \\
(0.009)\end{array}$ & $\begin{array}{l}-0.001 \\
(0.002)\end{array}$ & $\begin{array}{c}0.000 \\
(0.013)\end{array}$ & $\begin{array}{l}-0.001 \\
(0.010)\end{array}$ & $\begin{array}{l}-0.001 \\
(0.003)\end{array}$ & $\begin{array}{c}0.000 \\
(0.016)\end{array}$ \\
\hline Inflation rate & $\begin{array}{c}0.027 \\
(0.020)\end{array}$ & $\begin{array}{c}-0.0105^{* *} \\
(0.005)\end{array}$ & $\begin{array}{c}0.061 \\
(0.049)\end{array}$ & $\begin{array}{c}0.027 \\
(0.022)\end{array}$ & $\begin{array}{c}-0.0105^{* *} \\
(0.005)\end{array}$ & $\begin{array}{c}0.061 \\
(0.048)\end{array}$ \\
\hline Dependency ratio & $\begin{array}{c}-0.203^{* * *} \\
(0.038)\end{array}$ & $\begin{array}{l}-0.006 \\
(0.008)\end{array}$ & $\begin{array}{c}-0.180^{* * * *} \\
(0.049)\end{array}$ & $\begin{array}{c}-0.203^{* * *} \\
(0.042)\end{array}$ & $\begin{array}{l}-0.006 \\
(0.010)\end{array}$ & $\begin{array}{c}-0.180 * * * \\
(0.056)\end{array}$ \\
\hline Banking Crisis & $\begin{array}{c}0.087 \\
(0.115)\end{array}$ & $\begin{array}{l}-0.012 \\
(0.026)\end{array}$ & $\begin{array}{c}0.125 \\
(0.156)\end{array}$ & $\begin{array}{c}0.087 \\
(0.151)\end{array}$ & $\begin{array}{l}-0.012 \\
(0.028)\end{array}$ & $\begin{array}{c}0.125 \\
(0.191)\end{array}$ \\
\hline Liquid liabilities/GDP & $\begin{array}{c}0.427^{*} \\
(0.226)\end{array}$ & $\begin{array}{c}0.052 \\
(0.048)\end{array}$ & & $\begin{array}{c}0.427 \\
(0.262)\end{array}$ & $\begin{array}{c}0.052 \\
(0.055)\end{array}$ & \\
\hline L.Foreign Currency debt & $\begin{array}{c}-3.608^{* * *} \\
(1.097)\end{array}$ & $\begin{array}{c}0.221 \\
(0.204)\end{array}$ & $\begin{array}{c}-4.610^{* * *} \\
(1.545)\end{array}$ & $\begin{array}{c}-3.608^{* * *} \\
(1.125)\end{array}$ & $\begin{array}{c}0.221 \\
(0.239)\end{array}$ & $\begin{array}{c}-4.610^{* * *} \\
(1.579)\end{array}$ \\
\hline L.Effective Exchange rate & $\begin{array}{c}-0.033^{* * *} * \\
(0.006)\end{array}$ & $\begin{array}{c}0.001 \\
(0.001)\end{array}$ & $\begin{array}{c}-0.037^{* * *} \\
(0.009)\end{array}$ & $\begin{array}{c}-0.033^{* * *} \\
(0.006)\end{array}$ & $\begin{array}{c}0.001 \\
(0.001)\end{array}$ & $\begin{array}{c}-0.037 * * * \\
(0.010)\end{array}$ \\
\hline L.VE & & $\begin{array}{c}1.458^{* *} \\
(0.684)\end{array}$ & & & $\begin{array}{c}1.458^{* *} \\
(0.612)\end{array}$ & \\
\hline N. Obs. & 362 & 362 & 362 & 362 & 362 & 362 \\
\hline N. of countries & 17 & 17 & 17 & 17 & 17 & 17 \\
\hline
\end{tabular}

Notes: The table reports the regression coefficients and, in brackets, the associated Newey-West standard errors. * significant at $10 \% ; * *$ significant at $5 \%$; ** significant at $1 \%$. 
Table 7: Baseline regressions, controlling for foreign currency share and effective exchange rate and last growth spell starting in 2001

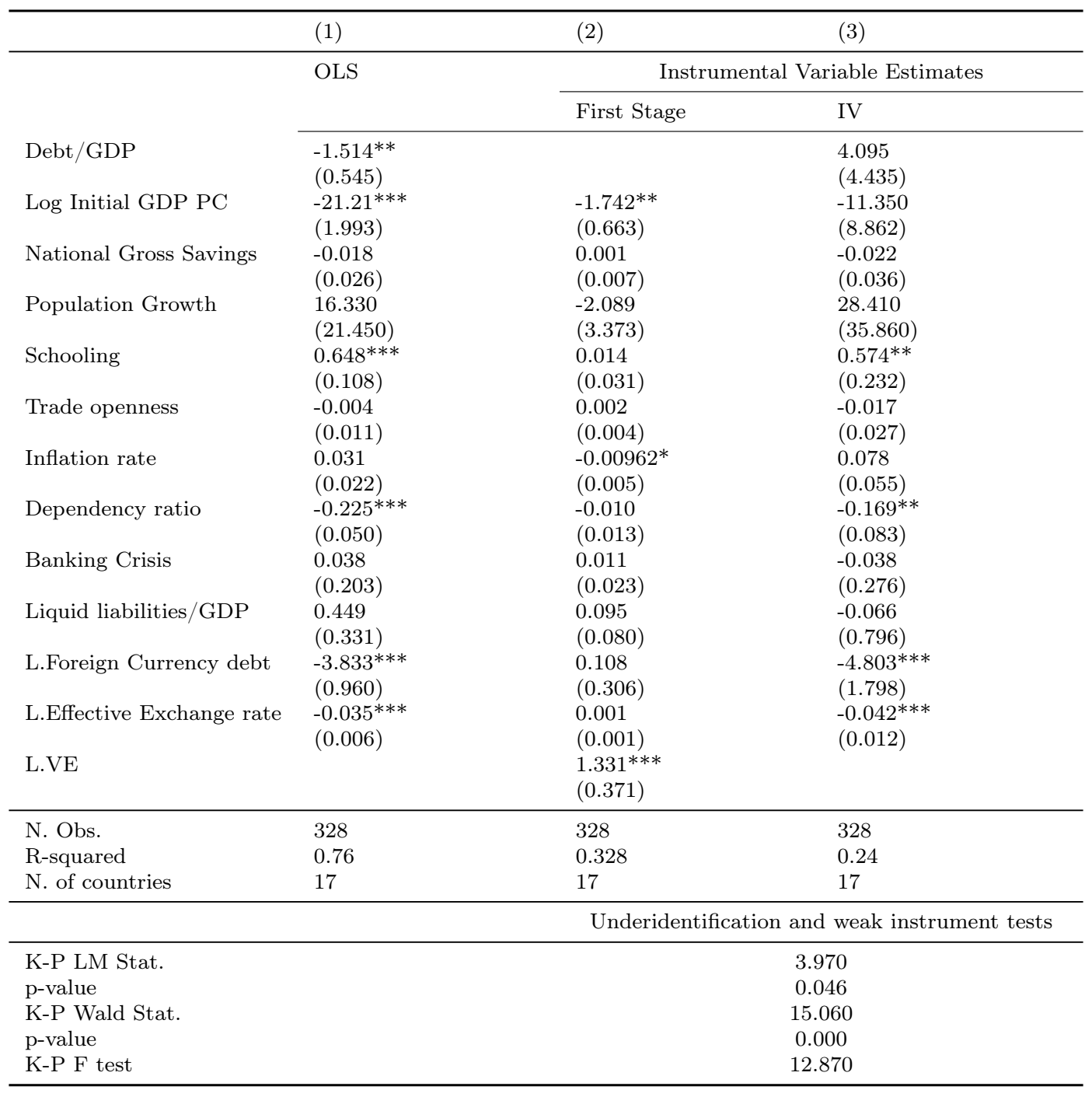

Notes: The table reports the regression coefficients and, in brackets, the associated robust (Hubert-White sandwich correction) standard errors. * significant at $10 \%$;* significant at $5 \%$; *** significant at $1 \%$. 
Table 8: Baseline regressions, controlling for foreign currency share and effective exchange rate, Excluding Japan

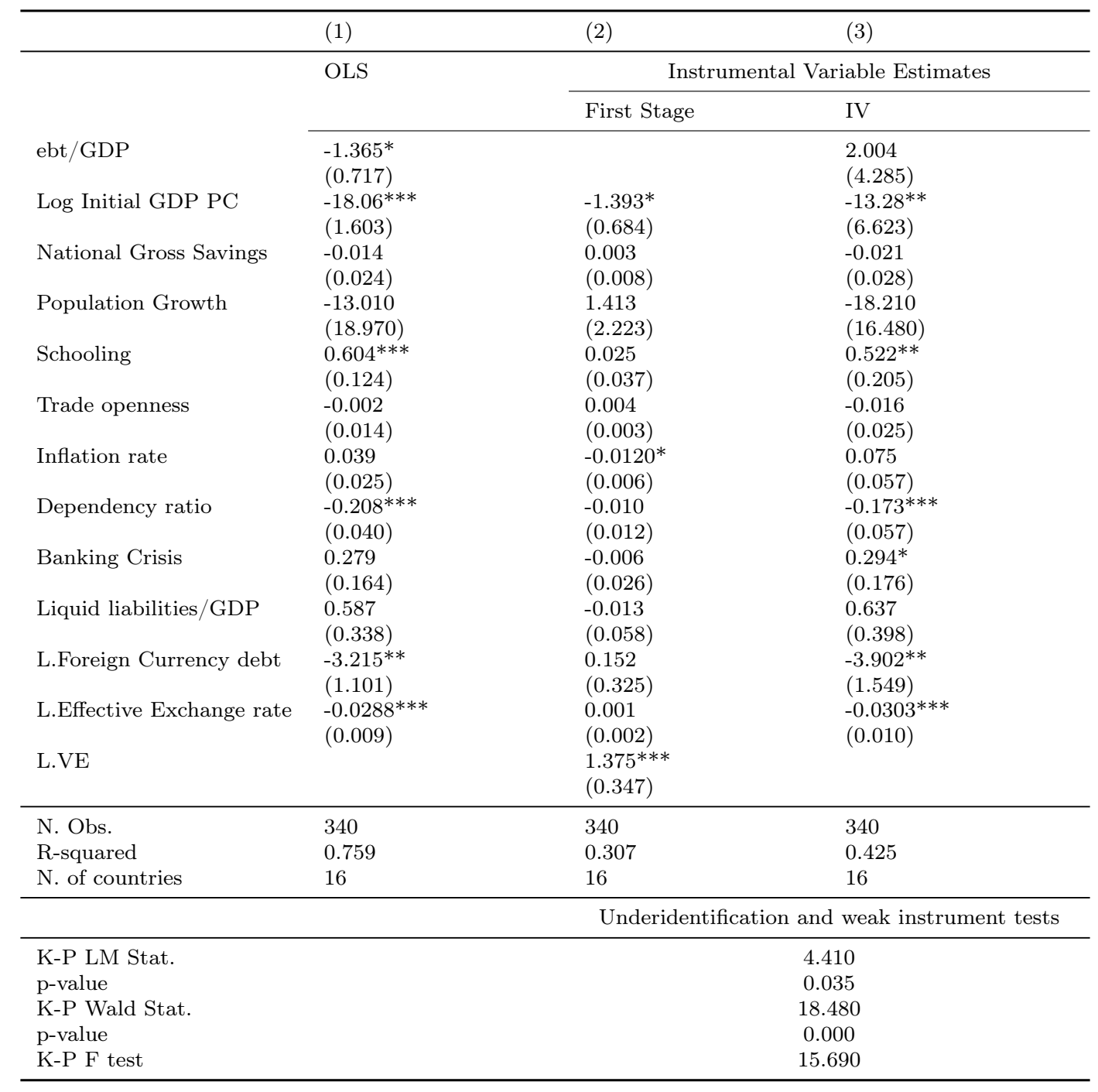

Notes: The table reports the regression coefficients and, in brackets, the associated robust (Hubert-White sandwich correction) standard errors. $*$ significant at $10 \% ; * *$ significant at $5 \% ; * * *$ significant at $1 \%$. 
Table 9: Baseline regressions, controlling for foreign currency share and effective exchange rate, alternative measure of public debt

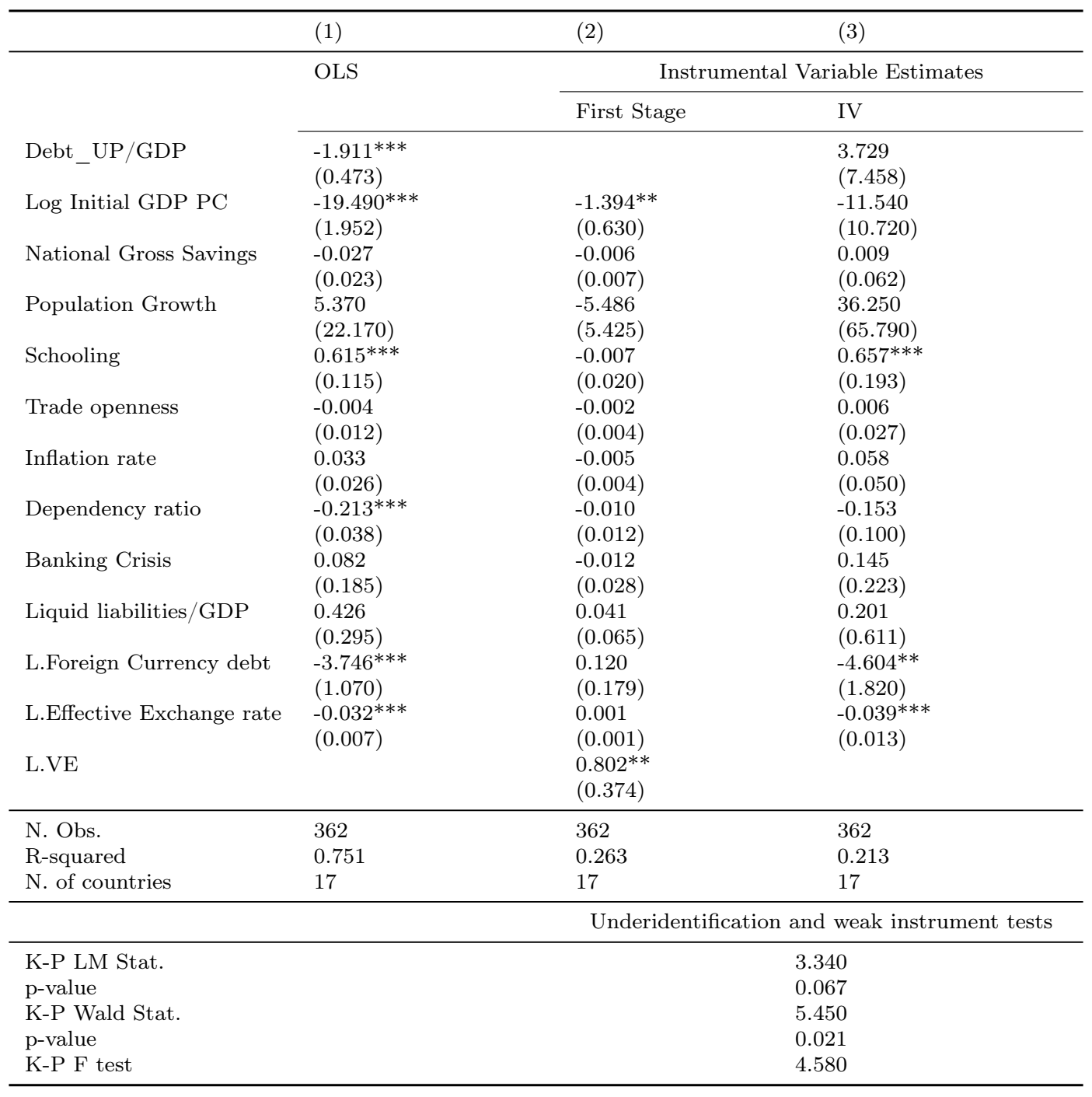

Notes: The table reports the regression coefficients and, in brackets, the associated robust (Hubert-White sandwich correction) standard errors. $*$ significant at $10 \% ; * *$ significant at $5 \% ; * * *$ significant at $1 \%$. 
Table 10: Baseline regressions, without outliers

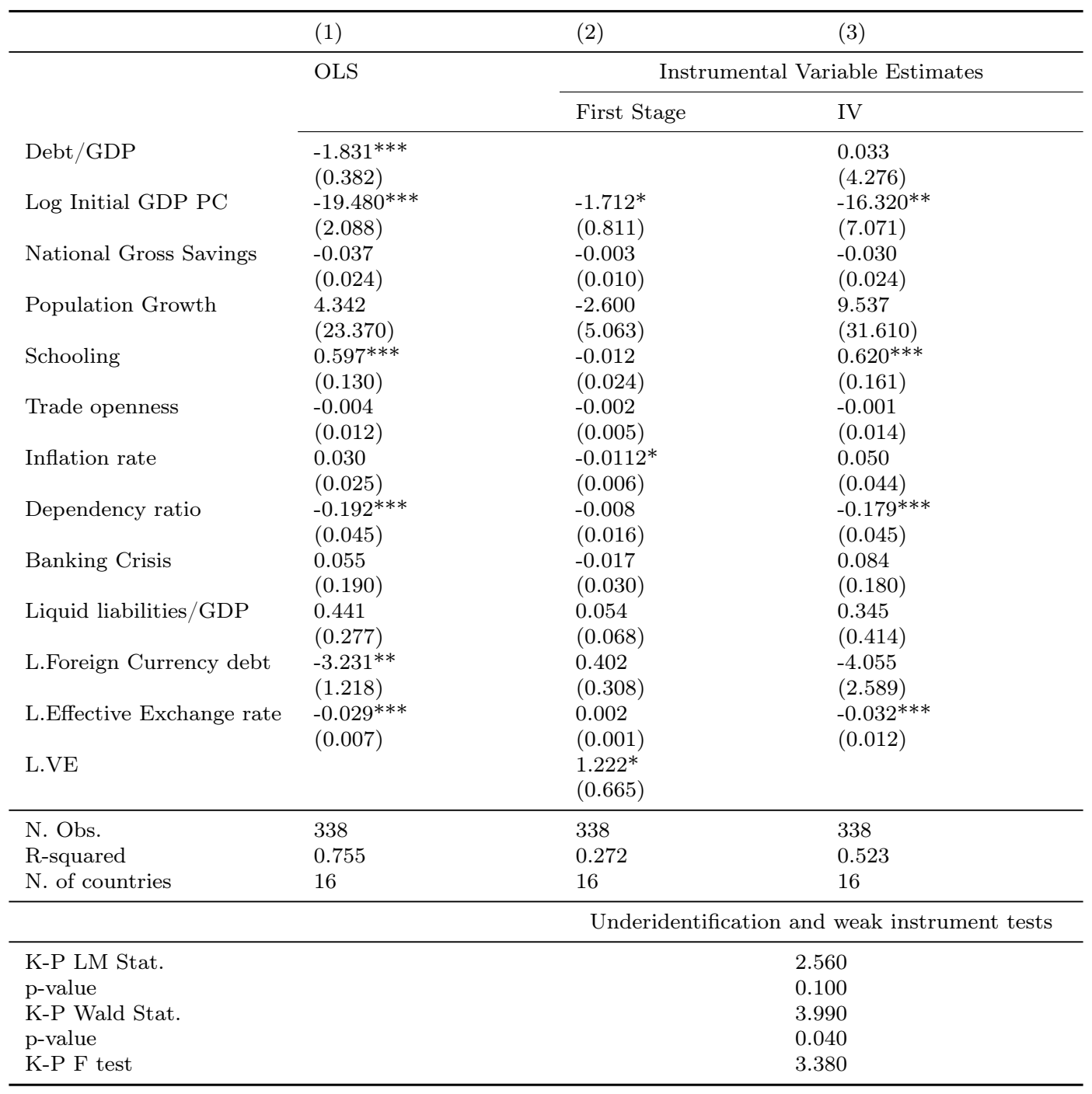

Notes: The table reports the regression coefficients and, in brackets, the associated robust (Hubert-White sandwich correction) standard errors. * significant at $10 \% ; * *$ significant at $5 \%$; *** significant at $1 \%$. 
Table 11: Non-overlapping growth spells

\begin{tabular}{|c|c|c|c|c|}
\hline & (1) & $(2)$ & (3) & (4) \\
\hline \multirow{3}{*}{ Starting in } & \multicolumn{4}{|c|}{ 3-year growth spells } \\
\hline & \multicolumn{2}{|c|}{$\begin{array}{c}\text { Second stage } \\
\text { coefficient of Debt/GDP }\end{array}$} & \multirow[t]{2}{*}{$\begin{array}{c}\text { First stage } \\
\text { coefficient of L.VE }\end{array}$} & \multirow[t]{2}{*}{$\begin{array}{l}\mathrm{K}-\mathrm{P} \\
\mathrm{F} \text { test }\end{array}$} \\
\hline & OLS & IV & & \\
\hline 1981 & $\begin{array}{c}-3.24^{* * *} \\
(1.27)\end{array}$ & $\begin{array}{c}7.74 \\
(8.43)\end{array}$ & $\begin{array}{c}0.28 \\
(1.88)\end{array}$ & 0.20 \\
\hline 1982 & $\begin{array}{c}-1.81^{* *} \\
(0.76)\end{array}$ & $\begin{array}{l}-2.71 \\
(4.61)\end{array}$ & $\begin{array}{c}2.55 \\
(1.39)\end{array}$ & 3.35 \\
\hline 1983 & $\begin{array}{c}-1.74^{* *} \\
(0.85)\end{array}$ & $\begin{array}{l}2.66 \\
(3.31)\end{array}$ & $\begin{array}{l}3.85^{* *} \\
(1.82)\end{array}$ & 4.48 \\
\hline \multirow[t]{2}{*}{ N. Obs. } & 119 & 119 & 119 & 119 \\
\hline & \multicolumn{4}{|c|}{ 5-year growth spells } \\
\hline \multirow[t]{2}{*}{ Starting in } & \multicolumn{2}{|c|}{$\begin{array}{c}\text { Second stage } \\
\text { coefficient of Debt/GDP }\end{array}$} & \multirow[t]{2}{*}{$\begin{array}{c}\text { First stage } \\
\text { coefficient of L.VE }\end{array}$} & \multirow[t]{2}{*}{$\begin{array}{l}\mathrm{K}-\mathrm{P} \\
\mathrm{F} \text { test }\end{array}$} \\
\hline & OLS & IV & & \\
\hline 1981 & $\begin{array}{c}-2.08^{* *} \\
(0.90)\end{array}$ & $\begin{array}{l}-9.16 \\
(7.72)\end{array}$ & $\begin{array}{c}3.12 \\
(3.67)\end{array}$ & 0.72 \\
\hline 1982 & $\begin{array}{c}-0.93 \\
(0.95)\end{array}$ & $\begin{array}{c}2.08 \\
(8.33)\end{array}$ & $\begin{array}{c}1.27 \\
(1.66)\end{array}$ & 0.58 \\
\hline 1983 & $\begin{array}{l}-1.30 \\
(1.32)\end{array}$ & $\begin{array}{c}48.36 \\
(73.91)\end{array}$ & $\begin{array}{c}0.53 \\
(0.82)\end{array}$ & 0.43 \\
\hline 1984 & $\begin{array}{l}-1.99 \\
(1.26)\end{array}$ & $\begin{array}{c}6.94 \\
(14.34)\end{array}$ & $\begin{array}{c}1.98 \\
(3.04)\end{array}$ & 0.42 \\
\hline 1985 & $\begin{array}{l}-1.73^{*} \\
(0.94)\end{array}$ & $\begin{array}{l}-0.54 \\
(3.02)\end{array}$ & $\begin{array}{c}4.28 * * * \\
(1.22)\end{array}$ & 12.27 \\
\hline N. Obs. & 68 & 68 & 68 & 68 \\
\hline
\end{tabular}

Notes: The table reports the regression coefficients and, in brackets, the associated robust (Hubert-White sandwich correction) standard errors. $*$ significant at $10 \%$;* significant at $5 \%$; *** significant at $1 \%$. 
Table 12: Regressions with 90\% thresholds

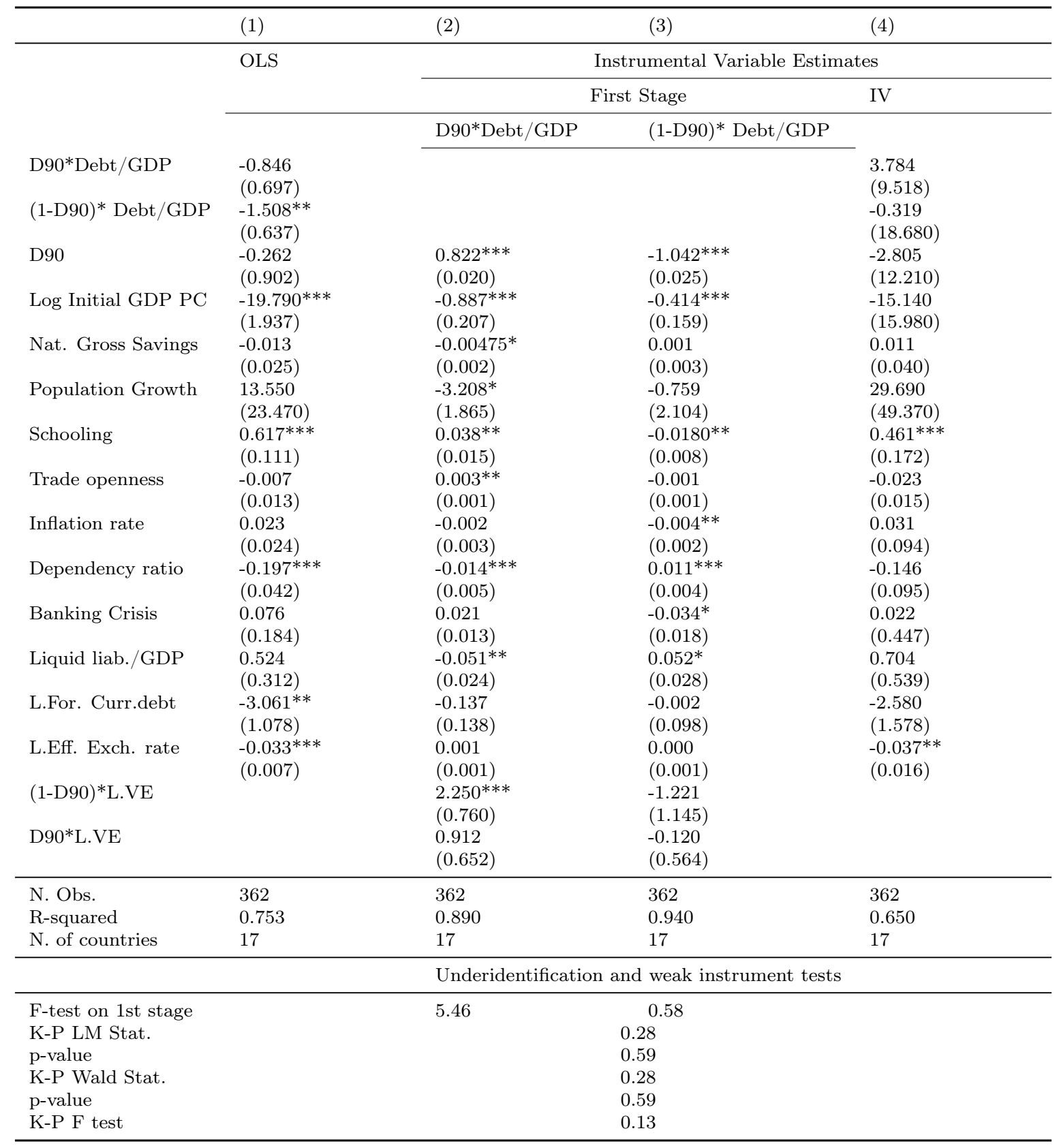

Notes: The table reports the regression coefficients and, in brackets, the associated robust (Hubert-White sandwich correction) standard errors. $*$ significant at $10 \%$; * significant at $5 \%$; ** significant at $1 \%$. 
Table 13: Regressions with debt below $90 \%$ thresholds

\begin{tabular}{|c|c|c|c|c|c|c|}
\hline & (1) & $(2)$ & (3) & $(4)$ & $(5)$ & (6) \\
\hline & OLS & \multicolumn{2}{|c|}{ IV } & OLS & \multicolumn{2}{|c|}{ IV } \\
\hline & \multicolumn{3}{|c|}{ First stage } & \multicolumn{3}{|c|}{ First stage } \\
\hline Debt/GDP & $\begin{array}{l}-0.743 \\
(0.852)\end{array}$ & & $\begin{array}{c}4.563 \\
(6.388)\end{array}$ & $\begin{array}{l}-0.041 \\
(1.195)\end{array}$ & & $\begin{array}{c}3.927 \\
(5.353)\end{array}$ \\
\hline Log Initial GDP PC & $\begin{array}{c}-18.440 * * * \\
(2.612)\end{array}$ & $\begin{array}{c}-0.865^{* * *} \\
(0.259)\end{array}$ & $\begin{array}{c}-13.700^{* *} \\
(5.755)\end{array}$ & $\begin{array}{c}-15.530^{* * *} \\
(2.356)\end{array}$ & $\begin{array}{c}-1.020^{* * *} \\
(0.196)\end{array}$ & $\begin{array}{c}-11.460^{* *} \\
(5.694)\end{array}$ \\
\hline Nat. Gross Savings & $\begin{array}{l}-0.025 \\
(0.034)\end{array}$ & $\begin{array}{l}-0.003 \\
(0.004)\end{array}$ & $\begin{array}{l}-0.006 \\
(0.032)\end{array}$ & & & \\
\hline Population Growth & $\begin{array}{c}1.062 \\
(26.350)\end{array}$ & $\begin{array}{l}-2.607 \\
(1.850)\end{array}$ & $\begin{array}{l}14.610 \\
(26.440)\end{array}$ & & & \\
\hline Schooling & $\begin{array}{c}0.571^{* * *} \\
(0.135)\end{array}$ & $\begin{array}{l}0.030^{*} \\
(0.015)\end{array}$ & $\begin{array}{c}0.407 \\
(0.251)\end{array}$ & & & \\
\hline Trade openness & $\begin{array}{l}-0.017 \\
(0.018)\end{array}$ & $\begin{array}{c}0.007^{* * *} \\
(0.002)\end{array}$ & $\begin{array}{l}-0.056 \\
(0.050)\end{array}$ & & & \\
\hline Inflation rate & $\begin{array}{c}0.039 \\
(0.036)\end{array}$ & $\begin{array}{l}-0.006 \\
(0.004)\end{array}$ & $\begin{array}{c}0.060 \\
(0.046)\end{array}$ & & & \\
\hline Dependency ratio & $\begin{array}{c}-0.219^{* * *} \\
(0.053)\end{array}$ & $\begin{array}{l}-0.007 \\
(0.005)\end{array}$ & $\begin{array}{c}-0.175^{* * *} \\
(0.054)\end{array}$ & & & \\
\hline Banking Crisis & $\begin{array}{c}0.265 \\
(0.286)\end{array}$ & $\begin{array}{c}0.021 \\
(0.014)\end{array}$ & $\begin{array}{c}0.158 \\
(0.185)\end{array}$ & & & \\
\hline Liq. liab/GDP & $\begin{array}{c}0.438 \\
(0.348)\end{array}$ & $\begin{array}{l}-0.030 \\
(0.030)\end{array}$ & $\begin{array}{l}0.611^{*} \\
(0.313)\end{array}$ & & & \\
\hline L.For. Curr. debt & $\begin{array}{c}-3.096^{* *} \\
(1.135)\end{array}$ & $\begin{array}{c}0.016 \\
(0.152)\end{array}$ & $\begin{array}{c}-3.395^{* * *} \\
(1.165)\end{array}$ & & & \\
\hline L.Eff. Exch. rate & $\begin{array}{c}-0.040^{* * * *} \\
(0.007)\end{array}$ & $\begin{array}{l}0.001^{* *} \\
(0.001)\end{array}$ & $\begin{array}{c}-0.047^{* * * *} \\
(0.012)\end{array}$ & & & \\
\hline L.VE & & $\begin{array}{l}1.254 \\
(0.815)\end{array}$ & & & $\begin{array}{l}1.443^{*} \\
(0.811)\end{array}$ & \\
\hline N. Obs. & 272 & 271 & 271 & 272 & 271 & 271 \\
\hline R-squared & 0.75 & 0.555 & 0.61 & 0.588 & 0.455 & 0.492 \\
\hline N. of countries & 17 & 16 & 16 & 17 & 16 & 16 \\
\hline & \multicolumn{4}{|c|}{$\begin{array}{l}\text { Underidentification and } \\
\text { weak instrument tests }\end{array}$} & \multicolumn{2}{|c|}{$\begin{array}{l}\text { Underidentification and } \\
\text { weak instrument tests }\end{array}$} \\
\hline K-P LM Stat. & \multicolumn{4}{|c|}{3.15} & \multicolumn{2}{|c|}{3.91} \\
\hline p-value & \multicolumn{4}{|c|}{0.07} & \multicolumn{2}{|c|}{0.04} \\
\hline K-P Wald Stat. & \multirow{2}{*}{\multicolumn{4}{|c|}{2.72}} & \multicolumn{2}{|c|}{3.48} \\
\hline $\mathrm{p}$-value & & & & & \multicolumn{2}{|c|}{0.06} \\
\hline K-P F test & \multicolumn{4}{|c|}{$\begin{array}{l}0.09 \\
2.37\end{array}$} & \multicolumn{2}{|c|}{3.16} \\
\hline
\end{tabular}

Notes: The table reports the regression coefficients and, in brackets, the associated robust (Hubert-White sandwich correction) standard errors. ${ }^{*}$ significant at $10 \% ; * *$ significant at $5 \% ; * * *$ significant at $1 \%$. 
Table 14: Regressions with debt above $90 \%$ thresholds

\begin{tabular}{|c|c|c|c|c|c|c|}
\hline & (1) & $(2)$ & (3) & (4) & $(5)$ & (6) \\
\hline & OLS & \multicolumn{2}{|c|}{ IV } & OLS & \multicolumn{2}{|c|}{ IV } \\
\hline & \multicolumn{3}{|c|}{ First stage } & \multicolumn{3}{|c|}{ First stage } \\
\hline Debt/GDP & $\begin{array}{c}-0.877 \\
(0.960)\end{array}$ & & $\begin{array}{l}-71.530 \\
(348.000)\end{array}$ & $\begin{array}{l}-1.525^{*} \\
(0.766)\end{array}$ & & $\begin{array}{c}3.069 \\
(5.244)\end{array}$ \\
\hline Log Init GDP PC & $\begin{array}{c}-17.82^{* * *} \\
(3.219)\end{array}$ & $\begin{array}{c}-4.023^{* * *} \\
(0.569)\end{array}$ & $\begin{array}{l}-301.500 \\
(1400.000)\end{array}$ & $\begin{array}{c}-20.59^{* * * *} \\
(3.241)\end{array}$ & $\begin{array}{c}-3.696^{* * *} \\
(0.590)\end{array}$ & $\begin{array}{l}-3.658 \\
(19.220)\end{array}$ \\
\hline Nat. Gross Sav. & $\begin{array}{l}-0.024 \\
(0.037)\end{array}$ & $\begin{array}{c}0.0205^{* *} \\
(0.008)\end{array}$ & $\begin{array}{l}1.424 \\
(7.241)\end{array}$ & & & \\
\hline Population Gr. & $\begin{array}{l}-76.140 \\
(90.540)\end{array}$ & $\begin{array}{l}-5.219 \\
(9.837)\end{array}$ & $\begin{array}{c}-458.200 \\
(1913.000)\end{array}$ & & & \\
\hline Schooling & $\begin{array}{c}0.096 \\
(0.392)\end{array}$ & $\begin{array}{c}0.025 \\
(0.065)\end{array}$ & $\begin{array}{c}1.647 \\
(7.589)\end{array}$ & & & \\
\hline Trade openness & $\begin{array}{l}-0.007 \\
(0.019)\end{array}$ & $\begin{array}{l}-0.004 \\
(0.003)\end{array}$ & $\begin{array}{l}-0.285 \\
(1.398)\end{array}$ & & & \\
\hline Inflation rate & $\begin{array}{c}0.002 \\
(0.014)\end{array}$ & $\begin{array}{l}-0.009 \\
(0.006)\end{array}$ & $\begin{array}{l}-0.609 \\
(3.029)\end{array}$ & & & \\
\hline Depend. ratio & $\begin{array}{l}-0.015 \\
(0.068)\end{array}$ & $\begin{array}{c}0.0293^{* * * *} \\
(0.011)\end{array}$ & $\begin{array}{c}2.083 \\
(10.310)\end{array}$ & & & \\
\hline Banking Crisis & $\begin{array}{c}0.192 \\
(0.238)\end{array}$ & $\begin{array}{l}-0.092 \\
(0.056)\end{array}$ & $\begin{array}{l}-6.284 \\
(32.590)\end{array}$ & & & \\
\hline Liq. liab/GDP & $\begin{array}{l}0.545 \\
(0.473)\end{array}$ & $\begin{array}{c}0.012 \\
(0.092)\end{array}$ & $\begin{array}{c}1.461 \\
(7.453)\end{array}$ & & & \\
\hline L.For. Curr. debt & $\begin{array}{c}2.976 \\
(3.389)\end{array}$ & $\begin{array}{l}-0.742 \\
(0.525)\end{array}$ & $\begin{array}{l}-48.530 \\
(246.700)\end{array}$ & & & \\
\hline L.Eff. Exch. rate & $\begin{array}{l}-0.008 \\
(0.010)\end{array}$ & $\begin{array}{l}-0.00847^{* * *} \\
\quad(0.002)\end{array}$ & $\begin{array}{l}-0.606 \\
(2.922)\end{array}$ & & & \\
\hline L.VE & & $\begin{array}{c}0.110 \\
(0.694) \\
\end{array}$ & & & $\begin{array}{l}-0.883 \\
(0.722) \\
\end{array}$ & \\
\hline N. Obs. & 90 & 90 & 90 & 90 & 90 & 90 \\
\hline R-squared & 0.831 & 0.817 & -29.776 & 0.777 & 0.627 & 0.51 \\
\hline N. of countries & 8 & 8 & 8 & 8 & 8 & 8 \\
\hline & \multicolumn{4}{|c|}{$\begin{array}{l}\text { Underidentification and } \\
\text { weak instrument tests }\end{array}$} & \multicolumn{2}{|c|}{$\begin{array}{l}\text { Underidentification and } \\
\text { weak instrument tests }\end{array}$} \\
\hline K-P LM Stat. & \multicolumn{4}{|c|}{0.04} & \multicolumn{2}{|c|}{1.42} \\
\hline p-value & \multicolumn{4}{|c|}{0.84} & \multicolumn{2}{|c|}{0.23} \\
\hline K-P Wald Stat. & \multirow{2}{*}{\multicolumn{4}{|c|}{$\begin{array}{l}0.04 \\
0.84\end{array}$}} & \multicolumn{2}{|c|}{2.04} \\
\hline p-value & & & & & \multicolumn{2}{|c|}{$\begin{array}{l}0.15 \\
1.49\end{array}$} \\
\hline K-P F test & \multicolumn{3}{|c|}{$\begin{array}{l}0.84 \\
0.02\end{array}$} & & & \\
\hline
\end{tabular}

Notes: The table reports the regression coefficients and, in brackets, the associated robust (Hubert-White sandwich correction) standard errors. ${ }^{*}$ significant at $10 \% ; * *$ significant at $5 \%$; ** significant at $1 \%$. 
Table 15: Identification through covariance restriction at different debt thresholds

\begin{tabular}{|c|c|c|c|c|}
\hline & (1) & $(2)$ & (3) & $(4)$ \\
\hline & \multicolumn{4}{|c|}{ (First) First Stage } \\
\hline TPGROWTH & $\begin{array}{c}0.055 \\
(0.232)\end{array}$ & $\begin{array}{c}-1.392^{* *} \\
(0.654)\end{array}$ & $\begin{array}{c}0.782^{* *} \\
(0.352)\end{array}$ & $\begin{array}{l}0.547^{*} \\
(0.304)\end{array}$ \\
\hline R-squared & 0.660 & 0.675 & 0.836 & 0.768 \\
\hline N. Obs. & 362 & 271 & 90 & 119 \\
\hline \multirow[t]{2}{*}{ N. of countries } & 17 & 16 & 8 & 8 \\
\hline & \multicolumn{4}{|c|}{ Underidentification and weak instrument tests } \\
\hline K-P LM Stat. & 0.06 & 4.35 & 7.37 & 3.73 \\
\hline p-value & 0.81 & 0.04 & 0.01 & 0.05 \\
\hline K-P Wald Stat. & 0.06 & 5.16 & 7.79 & 4.50 \\
\hline p-value & 0.80 & 0.02 & 0.01 & 0.03 \\
\hline K-P F test & 0.06 & 4.53 & 4.94 & 3.24 \\
\hline \multirow[t]{2}{*}{ Sample } & ALL & Debt $<90 \%$ & Debt $>90 \%$ & Debt $>80 \%$ \\
\hline & \multicolumn{4}{|c|}{ OLS and (Second) Second Stage } \\
\hline \multirow[b]{2}{*}{ Debt/GDP } & OLS & a3SLS & OLS & a3SLS \\
\hline & $\begin{array}{l}-0.747 \\
(1.076)\end{array}$ & $\begin{array}{c}12.960 * * \\
(6.022)\end{array}$ & $\begin{array}{l}-1.320^{*} \\
(0.632)\end{array}$ & $\begin{array}{c}28.031 \\
(26.514)\end{array}$ \\
\hline Sample & Debt $>90 \%$ & Debt $>90 \%$ & Debt $>80 \%$ & Debt $>80 \%$ \\
\hline
\end{tabular}

Notes: The table reports the regression coefficients and, in brackets, the associated robust (Hubert-White sandwich correction) standard errors. ${ }^{*}$ significant at $10 \%$; ${ }^{* *}$ significant at $5 \%$; ${ }^{* *}$ significant at $1 \%$. The model includes the same set of controls used in the benchmark regressions of Table 2 . Coefficients are not reported to save space. 


\section{B Figures}

Figure 1: Partial correlation between L.VE and Public Debt over GDP in first stage regression

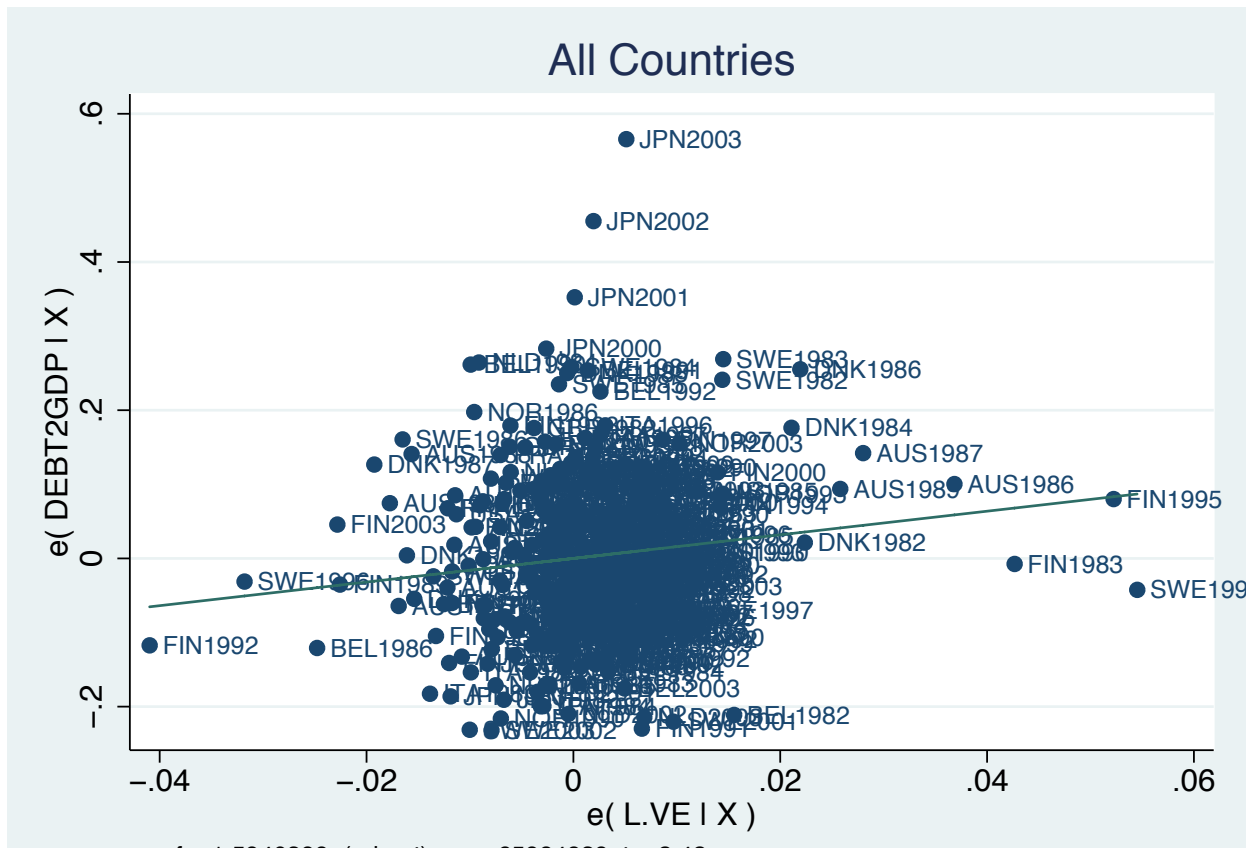

coef $=1.5940399$, (robust) $\mathrm{se}=.65984839, \mathrm{t}=2.42$ 
Figure 2: Partial correlation between L.VE and Public Debt over GDP in first stage regression, excluding Japan

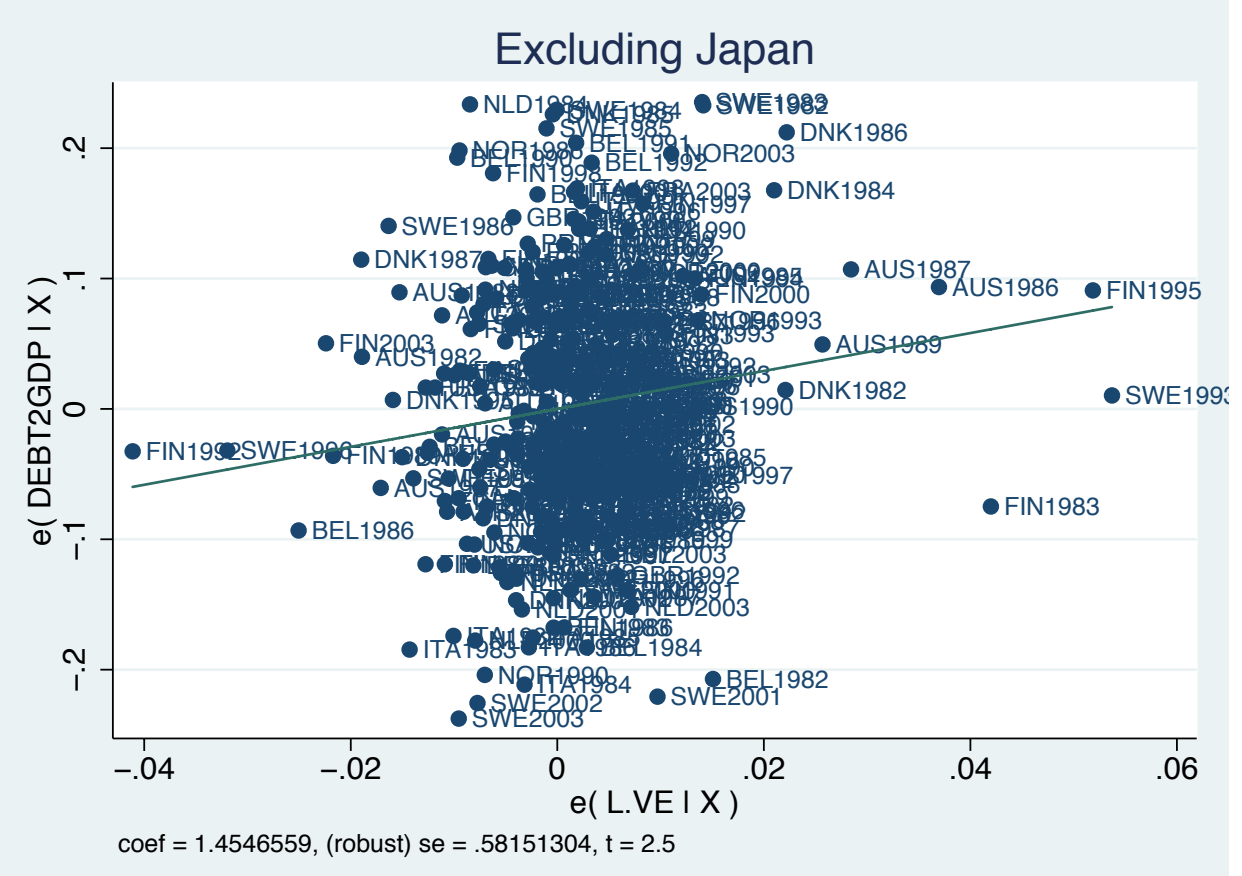

Figure 3: Partial correlation between L.VE and Public Debt over GDP in first stage regression, excluding countries with no foreign currency debt

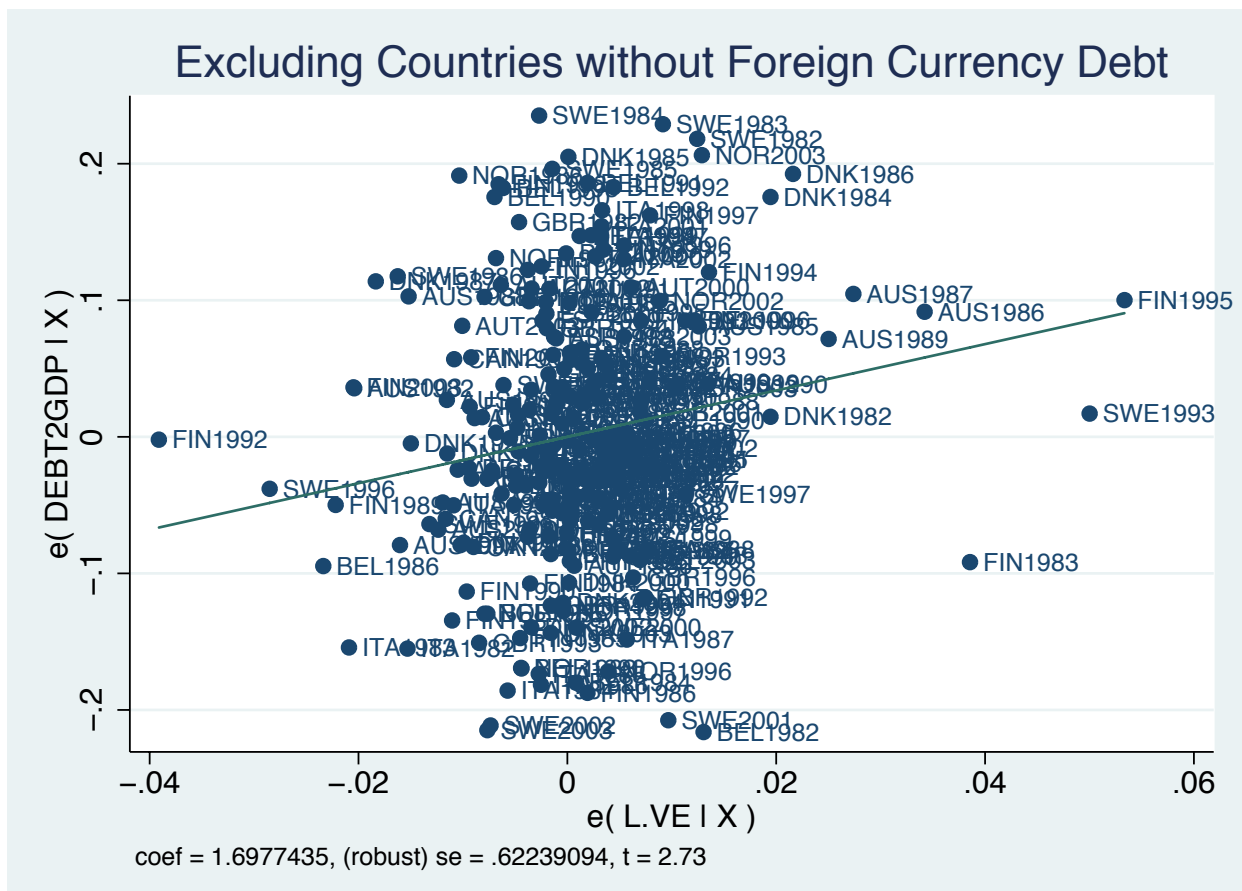


Figure 4: Placebo regressions

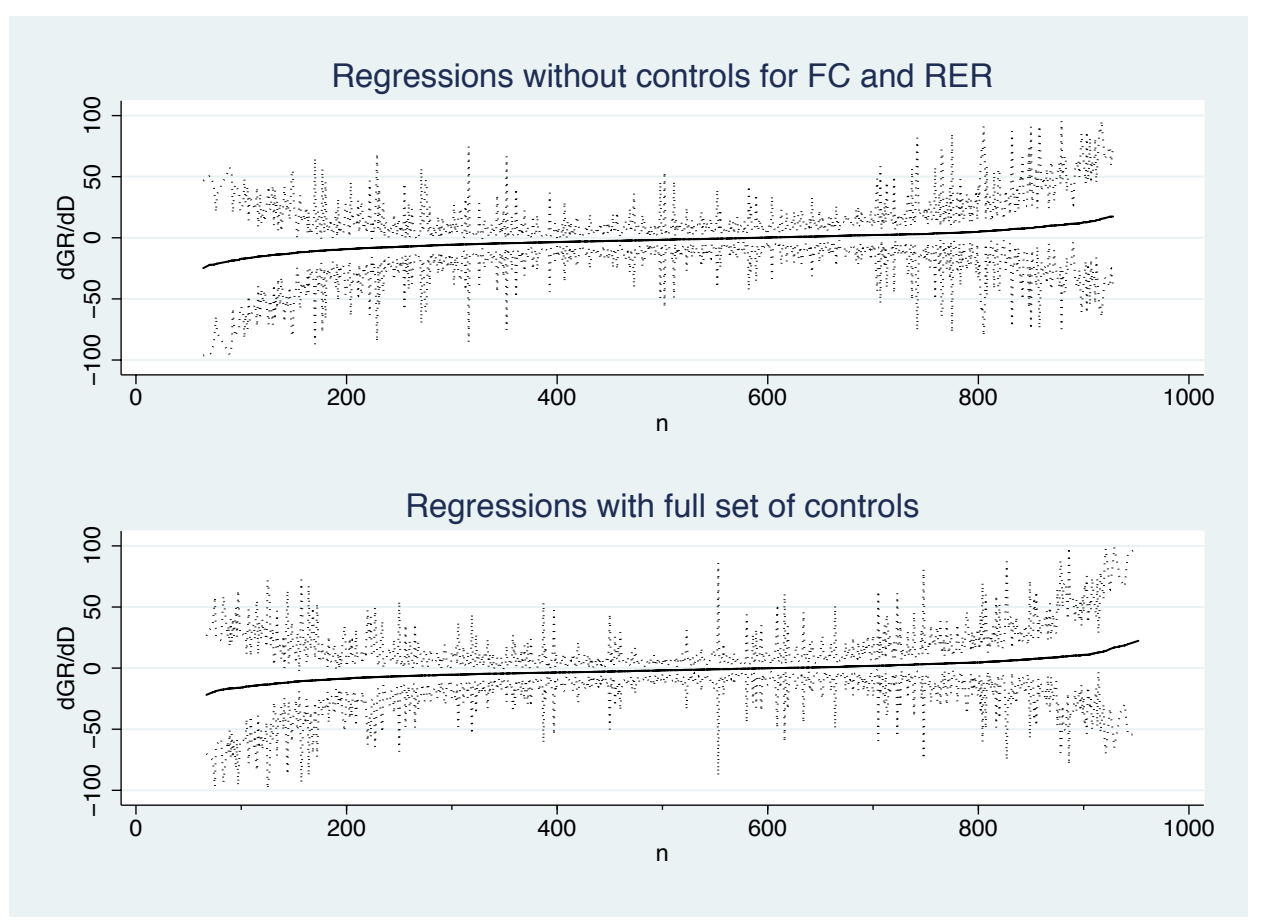

Notes: This figure plots the point estimates (with 95 percent confidence intervals) of the regressions described in Table 5 . To enhance readability we only plot observations for which the confidence interval ranges between -100 and +100 .

Figure 5: Partial correlations between debt and growth: OLS estimates (column 1, Table 3)

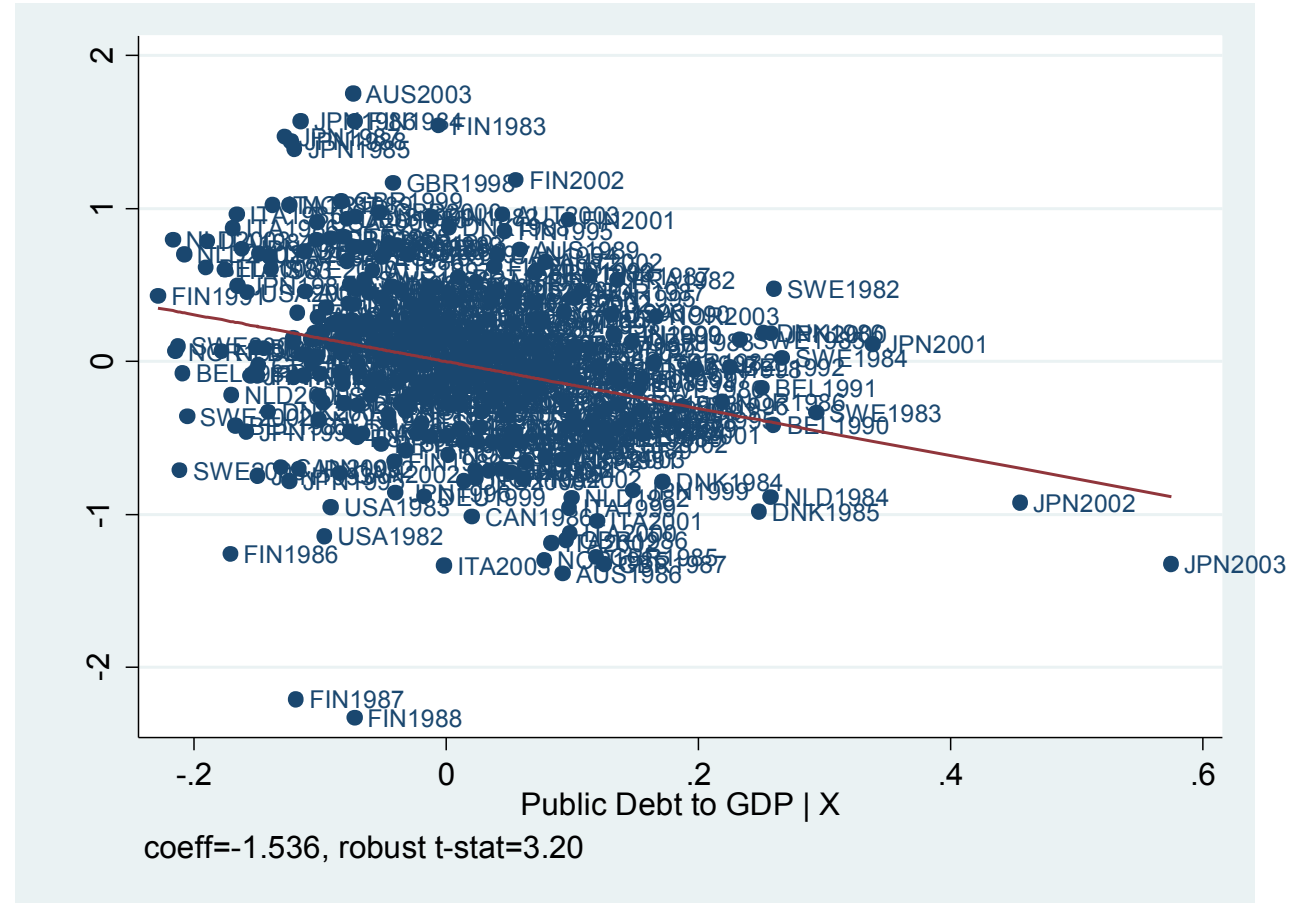


Figure 6: Partial correlations between debt and growth: IV estimates (column 3, Table 3)

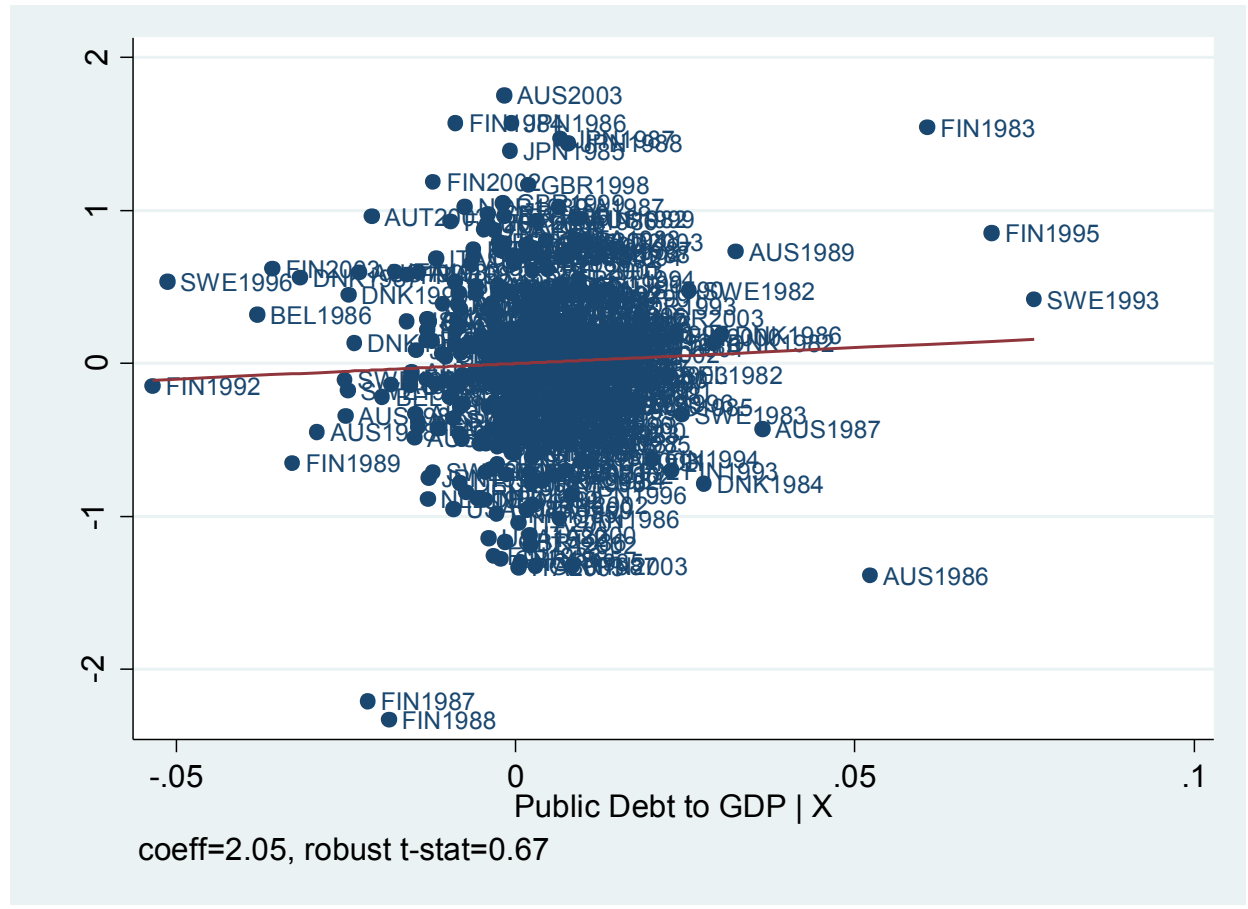

Figure 7: Leverage plot based on the IV estimates of column 3, Table 3

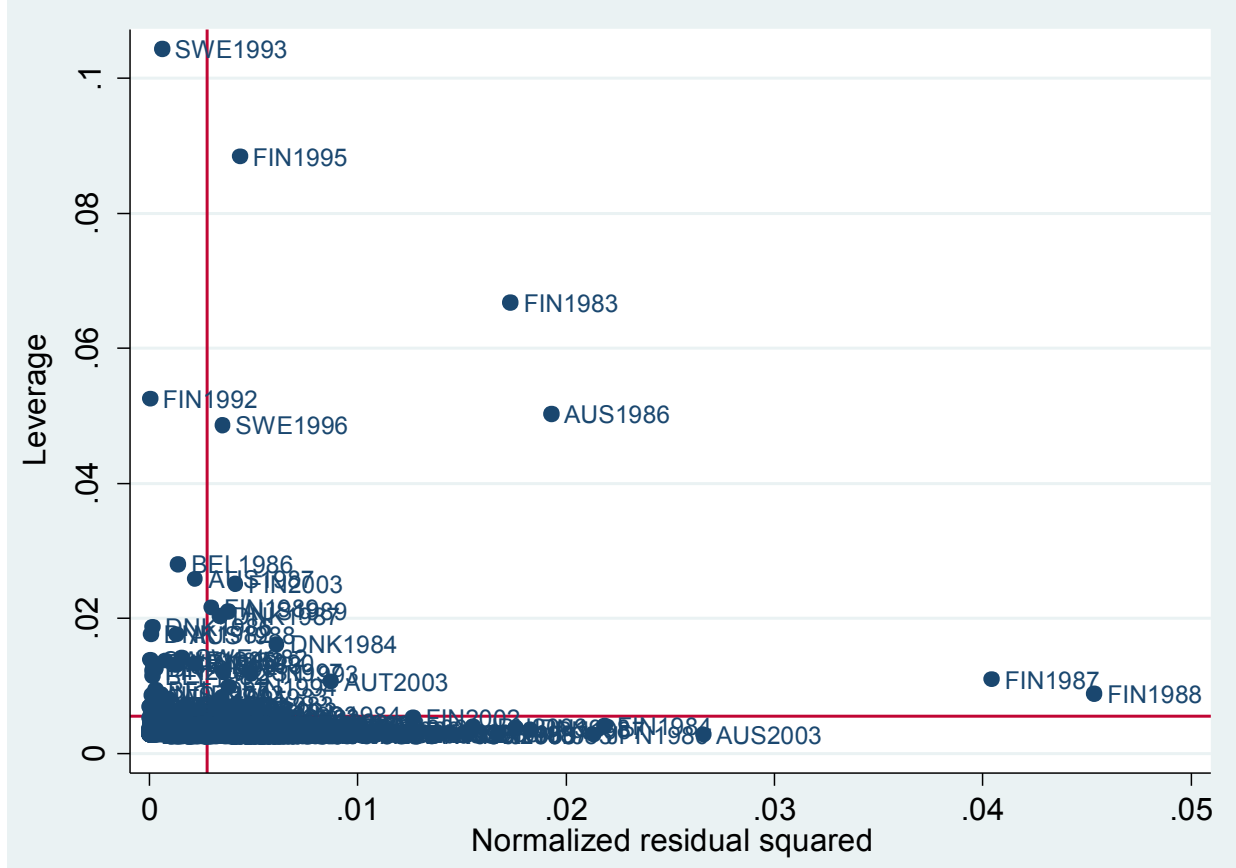


Figure 8: Partial correlations between debt and growth: OLS estimates without outliers (column 1, Table 10)

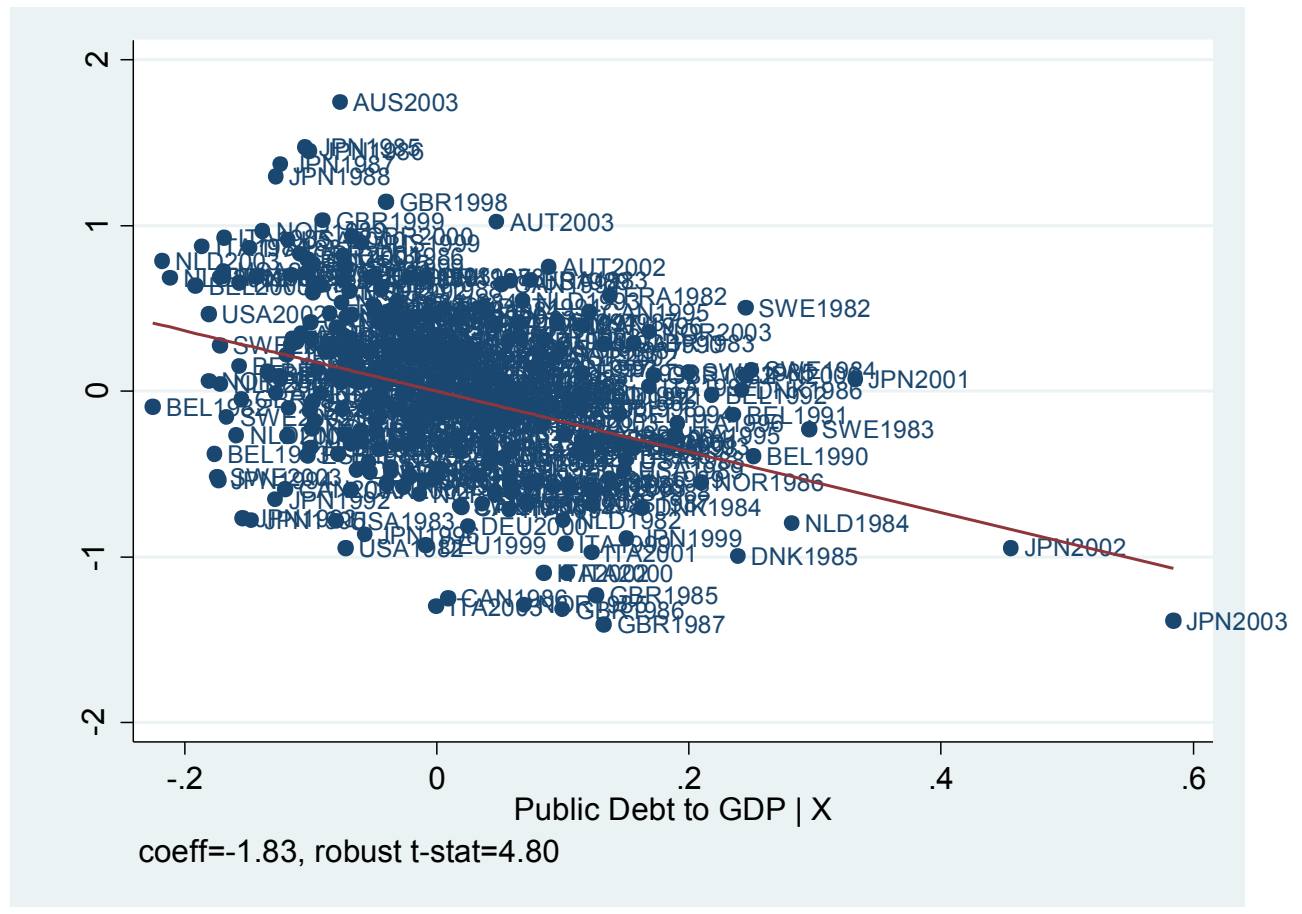

Figure 9: Partial correlations between debt and growth: IV estimates without outliers (column 3, Table 10)

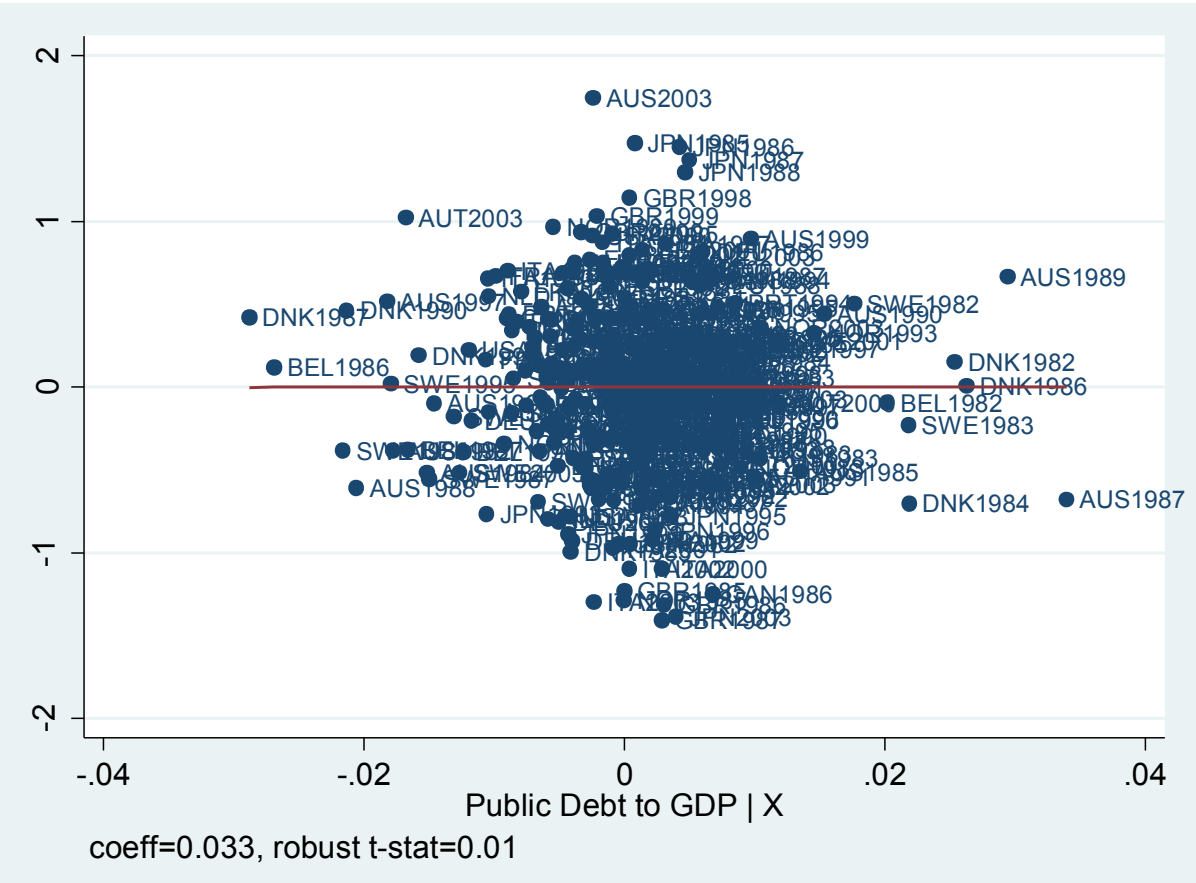


Figure 10: Hansen LR test for Threshold Regressions

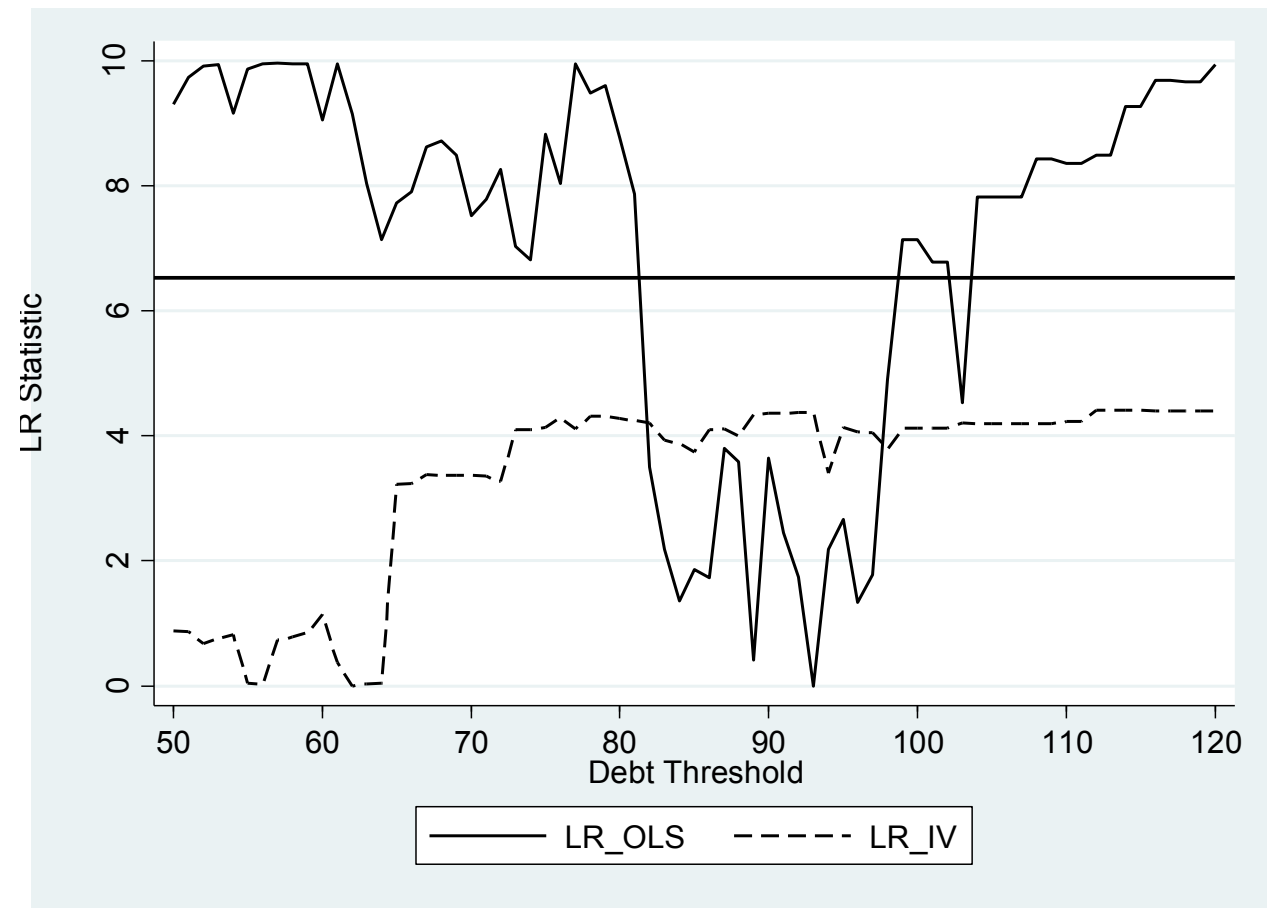

Notes: The solid line plots Hansen (1999) LR statistics obtained with OLS estimations of Equation 7. The dashed line plots the statistics obtained with IV estimates of the same equation. The horizontal line is the 10 percent critical value derived by Hansen (1999). 
Figure 11: Coefficients in OLS threshold regressions

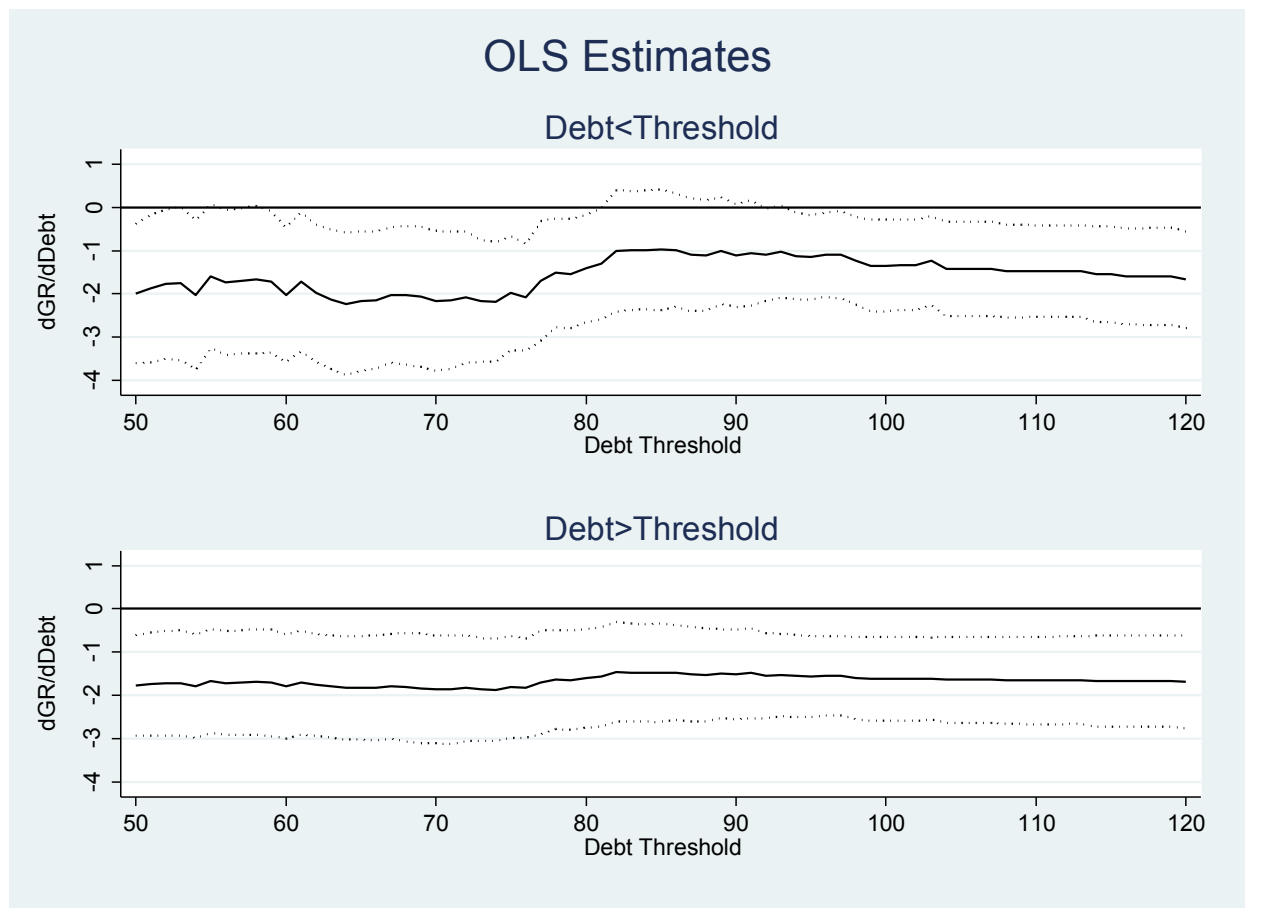

Notes: The solid lines plot the coefficients at different thresholds and the dotted lines are $95 \%$ confidence intervals. 
Figure 12: Difference in coefficients in OLS threshold regressions

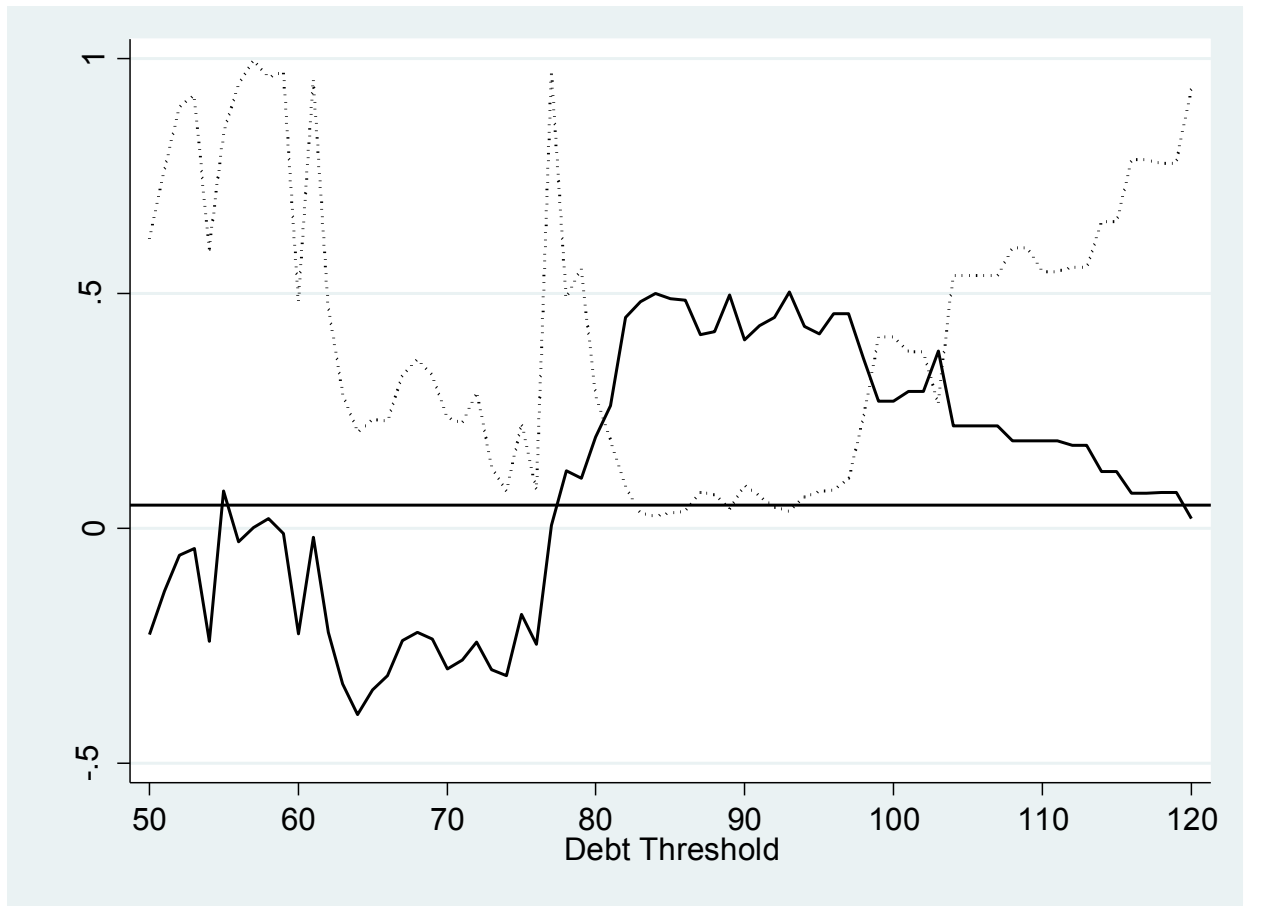

Notes: The solid line plots $\left(\frac{\partial G R O W T H}{\partial D e b t} \mid\right.$ Debt $<$ Threshold $)-\left(\frac{\partial G R O W T H}{\partial D e b t} \mid\right.$ Debt $>$ Threshold $)$. Since $\frac{\partial G R O W T H}{\partial D e b t}$ is always negative, a positive value indicates that the negative effect of debt on growth is larger above the threshold. The dotted line plots the p-value for the null hypothesis that $\left(\frac{\partial G R O W T H}{\partial D e b t} \mid\right.$ Debt $<$ Threshold $)-\left(\frac{\partial G R O W T H}{\partial D e b t} \mid\right.$ Debt $>$ Threshold $)=0$. The horizontal line is at 0.05 . Therefore, whenever the dotted line is above the horizontal line the difference between coefficients is not different form zero at the 5 percent confidence level. 
Figure 13: Coefficients in IV threshold regressions

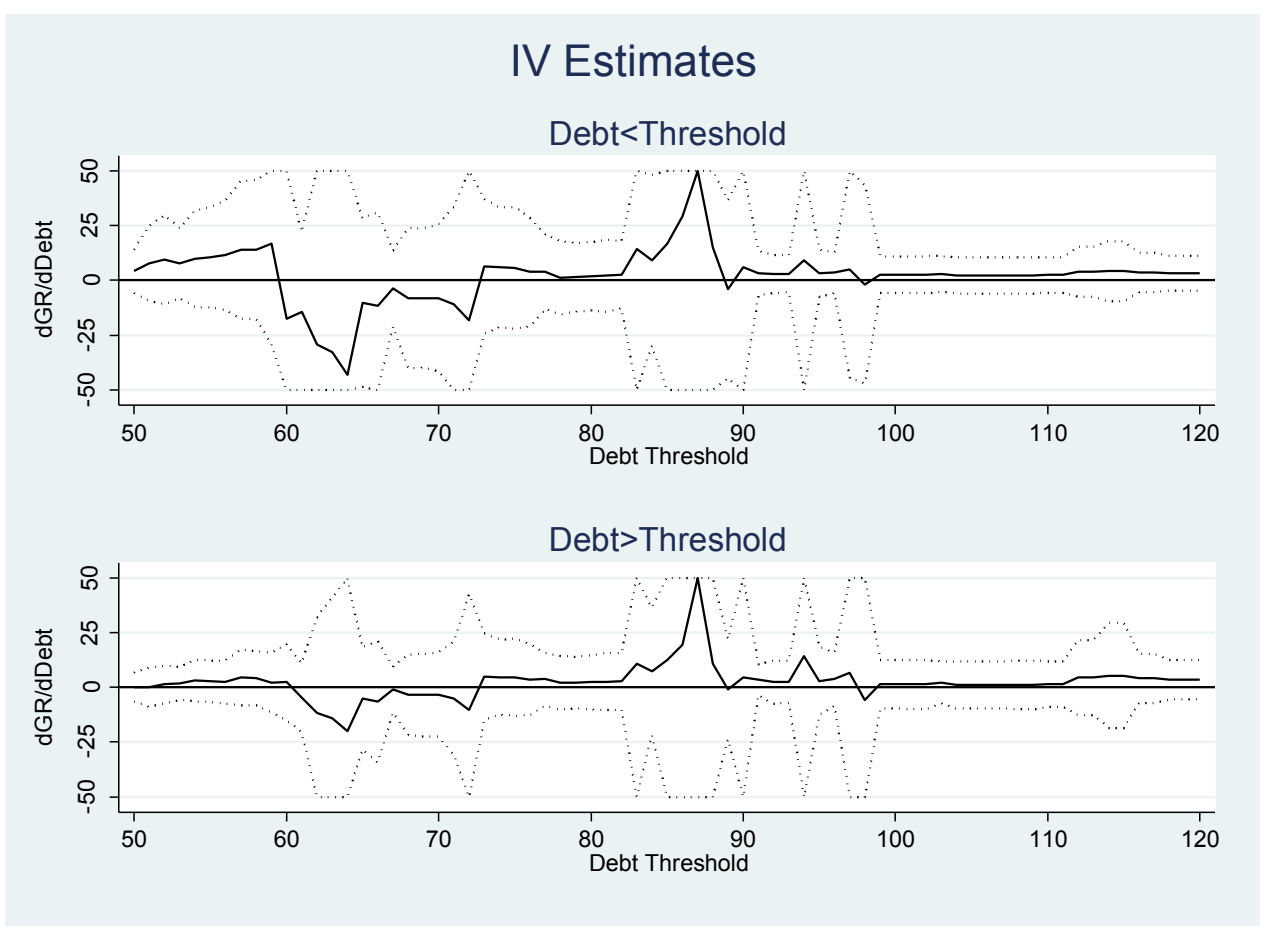

Notes: The solid lines plot the coefficients at different thresholds and the dotted lines are $95 \%$ confidence intervals. In the figure, we bounded the coefficients and standard errors at $(-50,50)$. 


\section{Additional Tables}

Table C.16: Summary Statistics

\begin{tabular}{|c|c|c|c|c|c|c|}
\hline & & Mean & Std. Dev. & Min & $\operatorname{Max}$ & N. Obs. \\
\hline \multirow{3}{*}{ Average 5-yr GDP per capita growth } & overall & 2.02 & 1.16 & -2.95 & 6.44 & $\mathrm{~N}=391$ \\
\hline & between & & 0.34 & 1.5 & 2.66 & $\mathrm{n}=17$ \\
\hline & within & & 1.12 & -2.99 & 5.8 & $\mathrm{~T}=23$ \\
\hline \multirow{3}{*}{ Debt/GDP } & overall & 0.74 & 0.3 & 0.19 & 1.9 & $\mathrm{~N}=476$ \\
\hline & between & & 0.24 & 0.43 & 1.2 & $\mathrm{n}=17$ \\
\hline & within & & 0.19 & 0.21 & 1.52 & $\mathrm{~T}=28$ \\
\hline \multirow{3}{*}{ Log Initial GDP PC } & overall & 10.21 & 0.25 & 9.27 & 10.84 & $\mathrm{~N}=476$ \\
\hline & between & & 0.19 & 9.66 & 10.53 & $\mathrm{n}=17$ \\
\hline & within & & 0.17 & 9.82 & 10.55 & $\mathrm{~T}=28$ \\
\hline \multirow{3}{*}{ National Gross Savings } & overall & 22.23 & 4.59 & 10.61 & 39.9 & $\mathrm{~N}=476$ \\
\hline & between & & 3.74 & 16.13 & 30.13 & $\mathrm{n}=17$ \\
\hline & within & & 2.81 & 11.68 & 32.59 & $\mathrm{~T}=28$ \\
\hline \multirow[t]{3}{*}{ Population Growth } & overall & $0.50 \%$ & $0.42 \%$ & $-0.34 \%$ & $2.10 \%$ & $\mathrm{~N}=459$ \\
\hline & between & & $0.34 \%$ & $0.18 \%$ & $1.31 \%$ & $\mathrm{n}=17$ \\
\hline & within & & $0.25 \%$ & $-0.10 \%$ & $1.56 \%$ & $\mathrm{~T}=27$ \\
\hline \multirow[t]{3}{*}{ Schooling } & overall & 8.95 & 1.88 & 3.78 & 12.05 & $\mathrm{~N}=476$ \\
\hline & between & & 1.82 & 4.97 & 11.85 & $\mathrm{n}=17$ \\
\hline & within & & 0.64 & 6.34 & 10.04 & $\mathrm{~T}=28$ \\
\hline \multirow[t]{3}{*}{ Trade openness } & overall & 64.16 & 30.8 & 16.11 & 170.53 & $\mathrm{~N}=476$ \\
\hline & between & & 30.16 & 22.41 & 139.85 & $\mathrm{n}=17$ \\
\hline & within & & 9.52 & 44.3 & 95.94 & $\mathrm{~T}=28$ \\
\hline \multirow[t]{3}{*}{ Inflation rate } & overall & 3.89 & 3.72 & -9.63 & 28.78 & $\mathrm{~N}=476$ \\
\hline & between & & 1.7 & 1.01 & 8.78 & $\mathrm{n}=17$ \\
\hline & within & & 3.34 & -8.18 & 23.88 & $\mathrm{~T}=28$ \\
\hline \multirow[t]{3}{*}{ Dependency ratio } & overall & 50.05 & 3.29 & 43.12 & 58.38 & $\mathrm{~N}=476$ \\
\hline & between & & 2.7 & 46.26 & 55.06 & $\mathrm{n}=17$ \\
\hline & within & & 1.98 & 46.24 & 59.05 & $\mathrm{~T}=28$ \\
\hline \multirow[t]{3}{*}{ Banking Crisis } & overall & 0.16 & 0.36 & 0 & 1 & $\mathrm{~N}=476$ \\
\hline & between & & 0.11 & 0.04 & 0.36 & $\mathrm{n}=17$ \\
\hline & within & & 0.35 & -0.2 & 1.12 & $\mathrm{~T}=28$ \\
\hline \multirow[t]{3}{*}{ Liquid liabilities/GDP } & overall & 0.75 & 0.38 & 0 & 2.42 & $\mathrm{~N}=476$ \\
\hline & between & & 0.34 & 0.43 & 1.93 & $\mathrm{n}=17$ \\
\hline & within & & 0.2 & -0.04 & 1.46 & $\mathrm{~T}=28$ \\
\hline \multirow[t]{3}{*}{ VE } & overall & $0.17 \%$ & $0.97 \%$ & $-3.41 \%$ & $7.50 \%$ & $\mathrm{~N}=464$ \\
\hline & between & & $0.26 \%$ & $-0.02 \%$ & $0.84 \%$ & $\mathrm{n}=17$ \\
\hline & within & & $0.94 \%$ & $-3.67 \%$ & $7.24 \%$ & T-bar $=27.29$ \\
\hline \multirow[t]{3}{*}{ Foreign Currency debt } & overall & 0.11 & 0.14 & 0 & 0.66 & $\mathrm{~N}=467$ \\
\hline & between & & 0.13 & 0 & 0.52 & $\mathrm{n}=17$ \\
\hline & within & & 0.05 & -0.09 & 0.28 & T-bar $=27.47$ \\
\hline \multirow{3}{*}{$\begin{array}{l}\text { Effective Exchange rate } \\
\text { (deviation form country average) }\end{array}$} & overall & -1.47 & 10.65 & -34.67 & 43.02 & $\mathrm{~N}=476$ \\
\hline & between & & 6.16 & -12.12 & 14.12 & $\mathrm{n}=17$ \\
\hline & within & & 8.82 & -29.4 & 27.42 & $\mathrm{~T}=28$ \\
\hline \multirow[t]{3}{*}{ Debt_UP/GDP } & overall & 0.61 & 0.30 & 0.10 & 1.95 & $\mathrm{~N}=467$ \\
\hline & between & & 0.26 & 0.2 & 1.12 & $\mathrm{n}=17$ \\
\hline & within & & 0.16 & 0.07 & 1.46 & $\mathrm{~T}$-bar $=27.47$ \\
\hline \multirow[t]{3}{*}{ TPGROWTH } & overall & 0.31 & 0.29 & -0.01 & 1.77 & $\mathrm{~N}=391$ \\
\hline & between & & 0.28 & 0.03 & 1.08 & $\mathrm{n}=17$ \\
\hline & within & & 0.12 & -0.42 & 0.99 & T-bar $=23$ \\
\hline
\end{tabular}

Notes: VE and Population Growth are reported in percentage here but used in levels in the regressions. 
Table C.17: Description and sources of the variables used in the paper

\begin{tabular}{|c|c|}
\hline Variable & Description and sources \\
\hline Average 5-yr GDP per capita growth & $\begin{array}{l}\text { Average five-year growth of real GDP per capita from period } t+1 \text { to pe- } \\
\text { riod } t+6 \text {. The original data are from the Penn World Tables. We used the } \\
\text { dataset provided with the Cecchetti et al. (2011) paper on the BIS website } \\
\text { at: http://www.bis.org/publ/work352.htm }\end{array}$ \\
\hline Log Initial GDP PC & Same source as above \\
\hline Banking Crisis & $\begin{array}{l}\text { Dummy variable that tables a value one in country-years with a banking crisis. } \\
\text { The original data are from Carmen Reinhart. We obtained the data from: } \\
\text { http://www.bis.org/publ/work352.htm }\end{array}$ \\
\hline Debt/GDP & $\begin{array}{l}\text { Public debt as a share of GDP based on national accounts (flow of funds) } \\
\text { data. We obtained the data from: http://www.bis.org/publ/work } 352 . h t m\end{array}$ \\
\hline Debt_UP/GDP & Public debt as a share of GDP. The data are from Panizza (2008) \\
\hline Dependency ratio & $\begin{array}{l}\text { Population aged } 0-15 \text { and older than } 64 \text { over population aged } 15-64 \text {. The } \\
\text { original data are from the World Bank's WDI. We obtained the data from: } \\
\text { http://www.bis.org/publ/work } 352 . \mathrm{htm}\end{array}$ \\
\hline Inflation rate & $\begin{array}{l}\text { CPI inflation. The original data are from the World Bank's WDI. We obtained } \\
\text { the data from: http://www.bis.org/publ/work } 352 . h t m\end{array}$ \\
\hline Liquid liabilities/GDP & $\begin{array}{l}\text { Liquid liability as a share of GDP (proxy for financial depth). The orig- } \\
\text { inal data are from the World Bank's WDI. We obtained the data from: } \\
\text { http://www.bis.org/publ/work } 352 . h t m\end{array}$ \\
\hline National Gross Savings & $\begin{array}{l}\text { The original data are from the IMF World Economic Outlook. We obtained } \\
\text { the data from: http://www.bis.org/publ/work } 352 . h t m\end{array}$ \\
\hline Population Growth & $\begin{array}{l}\text { The original data are from the World Bank's WDI. We obtained the data } \\
\text { from: http://www.bis.org/publ/work } 352 . h t m\end{array}$ \\
\hline Schooling & $\begin{array}{l}\text { Average years spent in school of population aged } 15 \text { and older. The Orig- } \\
\text { inal data are from Barro and Lee }(2010) \text {. We obtained the data from: } \\
\text { http://www.bis.org/publ/work } 352 . h t m\end{array}$ \\
\hline Trade openness & $\begin{array}{l}\text { Total trade as a share of GDP. The original data are from the Penn World } \\
\text { Tables. We obtained the data from: http://www.bis.org/publ/work } 352 . h t m\end{array}$ \\
\hline VE & $\begin{array}{l}\text { Valuation effect. This variable is described in great details in Section } 2 \text { of the } \\
\text { paper. }\end{array}$ \\
\hline Effective Exchange rate & $\begin{array}{l}\text { Real effective exchange rate (deviation from country mean). The data are } \\
\text { from: http://www.bis.org/publ/work } 352 . h t m\end{array}$ \\
\hline Foreign Currency debt & $\begin{array}{l}\text { Foreign currency public debt over total public debt. The sources are the same } \\
\text { as those for VE. }\end{array}$ \\
\hline TPGROWTH & $\begin{array}{l}\text { Trading Partners Growth. The construction of this variable is described in } \\
\text { great detail in Section } 5 \text {. The original data are from Panizza and Jaimovich } \\
\text { (2007) and the Correlates of War Project's Trade Data Set (Barbieri, Keshk } \\
\text { and Pollins, 2012, 2009). }\end{array}$ \\
\hline
\end{tabular}

